\title{
Az adósságfék-szabályok tapasztalatai a magyarországi lakossági hitelezésben*
}

\author{
Fáykiss Péter - Palicz Alexandr - Szakács János - Zsigó Márton
}

A 2008-as pénzügyi válság rámutatott arra, hogy egyrészt a bankrendszer erösen prociklikus müködésü, másrészt a lakossági hitelfelvevők sem képesek reálisan felmérni hosszú távú törlesztöképességüket. Az ebböl eredő túlzott kockázatvállalás, illetve a nem megfelelő banki kockázatfelmérés Magyarországon is jelentős banki veszteségekkel és a fizetési problémákkal szembesülö ügyfelek magas arányával jártak. Az MNB makroprudenciális hatóságként 2015 óta az ún. adósságfék-szabályok útján, preventiv módon korlátozza a lakosság túlzott eladósodottságának újbóli kialakulását. A nemzetközi gyakorlatokra és a hazai elöírások első két és fél évének eredményeire fókuszálva áttekintettük a hazai tapasztalatokat az adósságfék-szabályok kapcsán. Bár a bevezetés óta eltelt időszak rövidsége miatt csak elözetes következtetéseket érdemes levonni, elemzésünk alapján a hazai adósságfék-szabályok jelenleg - kalibrációjuknak megfelelöen - nem korlátozzák a fenntartható hitelezési folyamatokat, azonban érdemben segítik a hitelezés egészséges szerkezetének megtartását a túlzottan kockázatos hitelek visszatartásával.

Journal of Economic Literature (JEL) kódok: E32, E58, G21, R31

Kulcsszavak: pénzügyi stabilitás, ingatlanpiaci túlfútöttség, túlzott hitelezés, makroprudenciális politika, adósságfék-szabályok, hitelfedezeti mutató, jövedelemarányos törlesztőrészlet mutató

\section{Bevezetés}

A 2008-as pénzügyi válság egyértelmúen rámutatott arra, hogy a bankrendszer erősen prociklikus múködésű. A bankrendszerben jelen lévő piaci súrlódások és a változó kockázatérzékelés miatt a bankok és ügyfeleik körében egyes időszakokban túlzott kockázatvállalás terjed el, majd abban az esetben, ha ennek következtében pénzügyi válság alakul ki, túlságosan alacsony kockázatvállalás válik jellemzővé. A bankrendszer gazdasági és pénzügyi ciklusokra ráerősítő működése jelentős mértékű reálgazdasági veszteségekkel járhat, ezért a makroprudenciális politika egyik

* Jelen cikk a szerző nézeteit tartalmazza, és nem feltétlenül tükrözi a Magyar Nemzeti Bank hivatalos álláspontját.

Fáykiss Péter a Magyar Nemzeti Bank igazgatója. E-mail: faykissp@mnb.hu

Szakács János a Magyar Nemzeti Bank föosztályvezetője. E-mail: szakacsj@mnb.hu

Zsigó Márton a Magyar Nemzeti Bank elemzője. E-mail: zsigoma@mnb.hu

Palicz Alexandr a Magyar Nemzeti Bank elemzője.E-mail: palicza@mnb.hu

A magyar nyelvű kézirat első változata 2017. szeptember 25-én érkezett szerkesztőségünkbe.

DOI: http://doi.org/10.25201/HSZ.17.1.3461 
fő feladata a bankrendszer prociklikusságának mérséklése. Emellett világossá vált az is, hogy a lakossági hitelfelvevők egyedül nem minden esetben képesek reálisan felmérni a hosszú távú, változó makrogazdasági körülmények közötti törlesztőképességüket, így az egyenlő versenyfeltételek biztosítása érdekében is szükség lehet a túlzott eladósodást gátló szabályozói eszközök alkalmazására. Az elmúlt időszakban - annak ellenére, hogy a makroprudenciális eszközök aktívabb alkalmazása óta eltelt időszak sok országban még viszonylag rövid - több empirikus elemzés is megjelent azzal a biztató következtetéssel, hogy az aktívabb makroprudenciális politika nemcsak a reálgazdasági növekedés ingadozásainak mérséklését segítheti, de hosszabb távon ceteris paribus magasabb szintű gazdasági növekedéssel is jár (lásd például Boar et al. 2017).

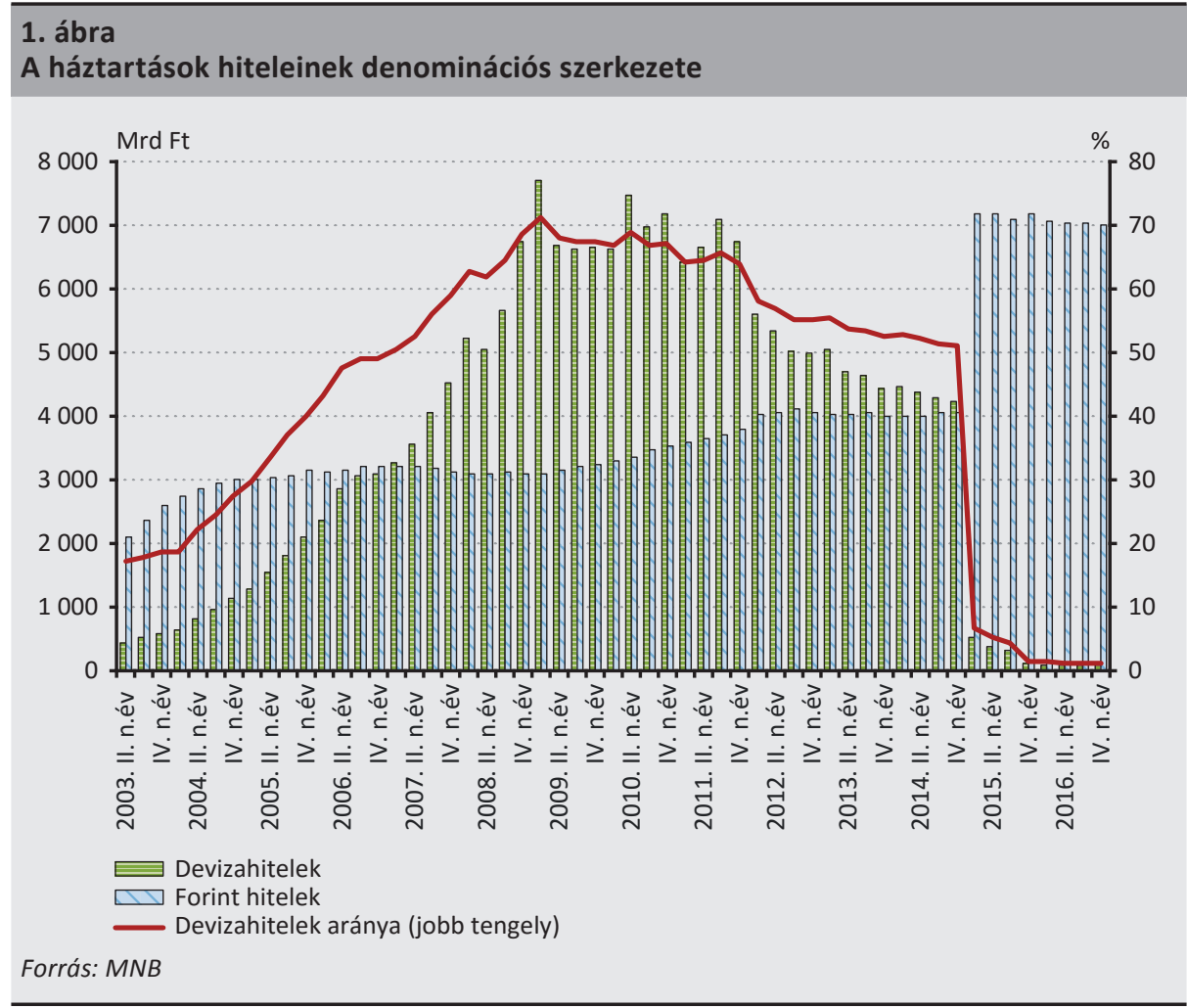

A túlzott kockázatvállalás lehetséges negatív hatásait jól mutatják a válság előtti hitelezés következményei Magyarországon. A visszafizetések valós kockázatai által indokoltnál lazább feltételek melletti hitelezés tekinthető túlzott mértékúnek. A válság előtti néhány évben Magyarországon mind a hitelállomány növekedése, mind pedig a devizahitelek tömeges elterjedése (1. ábra) arra utal, hogy a hiteltranzakciók egy rendszerszinten jelentős sokasága az ügyfelek oldaláról túlzott eladósodás, banki 
oldalról pedig túlzott kockázatvállalás mellett valósult meg, ráadásul a részt vevő felek kockázati várakozásai általánosságban is túlzottan optimisták voltak. Ennek következtében a válság kitörését követően drámaian megnőtt a fizetési problémákkal szembesülő ügyfelek száma. A megnövekvő nemteljesítő hitelállomány miatt a bankoknak jelentős mértékű értékvesztést kellett elszámolniuk, ami tőkeemeléseket is szükségessé tett 2008 és 2015 között. Az értékvesztés-képzés miatt csökkent a bankok szabad tőkéje, és a gazdasági kilátások miatt kockázatvállalási hajlandóságuk is drámaian mérséklődött, ami miatt jelentős mértékben visszaesett az új hitelek kihelyezése. Ez a válságban amúgy is csökkenő fogyasztást és beruházást még inkább visszafogta (2. ábra, lásd még Bauer et al. 2013).

\section{2. ábra \\ A lakossági hitelezés, valamint a válság alatt tapasztalt visszaesés a fogyasztásban, országonként}

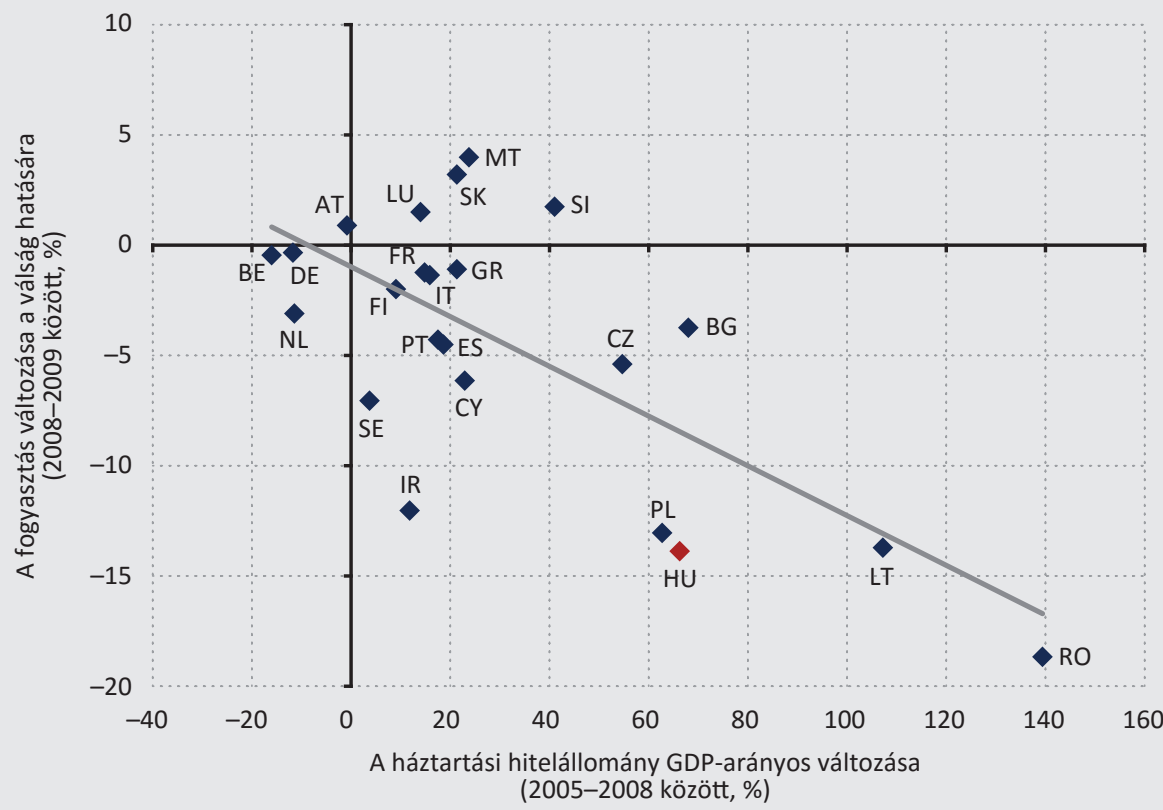

Forrás: EKB, Eurostat, nemzeti statisztikai hivatalok.

Az MNB makroprudenciális hatóságként 2015 óta az ún. adósságfék-szabályok útján, preventív módon korlátozza a lakosság túlzott eladósodottságának újbóli kialakulását. A kötelező érvényű, átfogó szempontrendszer alapján kialakított előírások hitelügyletszinten hatnak, így célzottan mérsékelhetik a túlhitelezésből eredő kockázatokat, ezáltal erősítve a pénzügyi stabilitást. A felállított limitek elsődleges célja, hogy a hitelállomány növekedése egészséges szerkezetben és fenntartható módon valósuljon meg, illetve egy jövőbeli esetleges túlfütöttség kialakulása 
esetén mérsékelje a túlzott hitelkiáramlás kialakulásának kockázatát. Tekintettel az adósságfék-előírások lehetséges széleskörű hatásaira, érdemes áttekinteni az elmúlt időszak kapcsolódó tapasztalatait.

A következőkben először megvizsgáljuk a túlzott lakossági eladósodottsághoz gyakran érdemben hozzájáruló ingatlanpiaci árbuborékok és a háztartási hitelezés kapcsolatát. Ezt követően számba vesszük a túlzott hitelezés kockázatainak mérséklésére hivatott adósságfék-jellegű előírások makroprudenciális eszközként való alkalmazhatóságát és nemzetközi mintákon becsült hatásosságát, majd áttekintjük az európai országokban bevezetett adósságfék-szabályok eddigi tapasztalatait. Végül a hazai előírások első két és fél évének eredményeit vesszük górcső alá, kitérve a hazai hitelezési folyamatok alakulására, a limitek eddig tapasztalható hatásaira és lehetséges mellékhatásaira is.

\section{A túlzott lakossági eladósodottság és az ingatlanár-buborékok}

A túlzott lakossági eladósodásnak különösen súlyos következményei lehetnek, ha lakóingatlan-piaci árbuborék felfúvódásával, azaz a lakóingatlanok árának általános, tartós és gyakran robbanásszerű túlértékeltségével együtt valósul meg. Ha a túlértékeltséget követő árkorrekció a lakosság túlzott eladósodottsága mellett megy végbe, az súlyos reálgazdasági recessziót, pénzügyi és bankválságot okozhat. Több tanulmány is megerősíti, hogy a hitelezés által fütött ingatlanpiaci buborék kifulladását követő gazdasági visszaesés költségesebb és potenciálisan hosszabb más típusú pénzügyi egyensúlytalanságok által felerősített recessziós időszakoknál (lásd például Claessens et al. 2009; Crowe et al. 2013; Jordà et al. 2015).

A lakóingatlan a háztartások vagyonának, míg a háztartási jelzáloghitelek a bankrendszer eszközállományának jelentős részét teszik ki. A lakáshitelek tömeges nemteljesítővé válása az értékvesztés-képzésen keresztül negatívan hat a banki jövedelmezőségre, ami a csökkenő banki tőkeszint miatt rontja a bankrendszer hitelezési képességét. A lakóingatlanok értékének csökkenésére a háztartások és a fedezeti érték csökkenésén keresztül a bankok is jelentős veszteséget szenvednek el eszközeiken, bár ez a háztartások esetében nem jelent azonnali hatást. A magyar háztartásokat ez különösen érzékenyen érintheti, ugyanis jellemző a jövedelmi helyzettől függetlenül magas lakástulajdonlási arány (csaknem 86,3 százalék 2016-ban ${ }^{1}$, ráadásul az alacsonyabb jövedelmű háztartások körében a lakóingatlan az egyetlen erősen domináns vagyonelem (lásd Boldizsár et al. 2016). A lakásvagyon hitelfelvételen keresztüli finanszírozása a hitelfelvevők többsége számára nagymértékű kötelezettségvállalással jár, amely az ingatlanérték csökkenése után is hosszú távon lekötheti a háztartások bevételeinek fogyasztásra vagy megtakarításra szánt részét

\footnotetext{
${ }^{1}$ A részletes adatokért lásd: http://appsso.eurostat.ec.europa.eu/nui/show.do?dataset=ilc_lvho02\&lang=en
} 
(„debt overhang problem”), és a fedezeti érték csökkenésével szigorúbb likviditási korláttal szembesítheti a hitelfelvevőket.

Az intenzív lakáshitel-kiáramlás felerősítheti az ingatlanpiaci egyensúlytalanságot. Bizonyos ingatlanpiaci mechanizmusok a túlzott hitelkiáramlás kialakulása nélkül is megnehezítik az egyensúlyi árszint tartós fennállását és gyors korrekcióját. Ilyenek például az információs aszimmetriából fakadó problémák, a relatíve magas tranzakciós költségek és a kínálati oldal alkalmazkodási képességének korlátai az építőipari és szabályozási adottságok miatt. A lakáspiaci tranzakciók azonban tipikusan jelentős hitelfelvételt igényelnek a vevői oldalon. A hitelkiáramlás bővülésével az ingatlankereslet bővülése is lehetővé válik, ami hozzájárul az ingatlanár-emelkedéshez. Az áremelkedés a háztartási vagyon, illetve a fedezeti érték emelkedésével tovább erősítheti a hitelkiáramlást, ami megjelenhet a lakáspiac bővülő keresletében, valamint az ingatlanfedezetek fogyasztási célú hitelhez való igénybevételében is (lásd például a szabadfelhasználású jelzáloghitelek elterjedését a válság előtt). Ahogy az 1. táblázat kínálta összefoglalásból látható, a hitelezés és ingatlanárak kölcsönhatását a szakirodalom több helyen megerősíti, bár a kölcsönhatás rövid és hosszú távú irányát illetően némileg eltérő megállapításokra jut. Átmenetileg megnőhet az építőipar és a másodkörös reálgazdasági hozzájárulás a GDP-hez. Ha azonban az amplifikációs mechanizmus hosszú távon fenntarthatatlan mértékú árés hitelállomány-növekedéshez vezet, akkor az építőipari és kapcsolt tevékenységek túlzott növekedése az erőforrások szuboptimális allokációjának tekinthető, aminek kedvezőtlen öröksége a buborék kifulladása után hosszú árnyékot vethet a gazdaság növekedési potenciáljára (lásd például Borio et al. 2016).

\begin{tabular}{|c|c|c|c|c|c|c|}
\hline \multicolumn{7}{|c|}{$\begin{array}{l}\text { 1. táblázat } \\
\text { Áttekintés a lakásárak és a hitelezés kölcsönhatásáról szóló tanulmányok kapcsán }\end{array}$} \\
\hline & \multicolumn{3}{|c|}{ Hosszú távú kölcsönhatás } & \multicolumn{3}{|c|}{ Rövid távú kölcsönhatás } \\
\hline Szerző & $\begin{array}{c}\text { lakásárak } \\
\downarrow \\
\text { hitelezés }\end{array}$ & $\begin{array}{l}\text { lakásárak } \\
\uparrow \\
\text { hitelezés }\end{array}$ & $\begin{array}{c}\text { lakásárak } \\
\downarrow \\
\text { hitelezés }\end{array}$ & $\begin{array}{c}\text { lakásárak } \\
\downarrow \\
\text { hitelezés }\end{array}$ & $\begin{array}{l}\text { lakásárak } \\
\uparrow \\
\text { hitelezés }\end{array}$ & \begin{tabular}{|c} 
lakásárak \\
$\uparrow$ \\
hitelezés
\end{tabular} \\
\hline Hoffmann (2003) & $*$ & & & & & $*$ \\
\hline Hoffmann (2004) & $*$ & & & & & \\
\hline Brissimis és Vlassopoulos (2009) & * & & & & & * \\
\hline Gerlach és Peng (2005) & $*$ & & & $*$ & & \\
\hline Oikarinen (2009a, 2009b) & & * & & & * & \\
\hline Fitzpatrick és McQuinn (2007) & & & $*$ & & $*$ & \\
\hline Berlinghieri (2010) & & & $*$ & & & $*$ \\
\hline $\begin{array}{l}\text { Gimeno és Martinez-Carrascal } \\
\text { (2010) }\end{array}$ & & & * & & & \\
\hline
\end{tabular}

Megjegyzés: A csillagok jelölik azokat az eseteket, ahol a tanulmányok hatásokat azonosítottak a lakásárak és a hitelezés között.

Forrás: Anundsen - Jansen (2013). 
Az empirikus szakirodalom alapján a túlzott háztartási eladósodottsággal növekszik a valószínúsége az ingatlanpiaci egyensúlytalanságok és a súlyos pénzügyi krízisek létrejöttének. Az eszközár-buborékok között egyes vizsgálatok megkülönböztetik a hitelezés által fütött és a spekulatív tőkebefektetéssel finanszírozott („,irrational exuberance") folyamatokat (Mishkin 2008). Crowe et al. (2013) nemzetközi mintáján az ingatlanpiaci buborékok az esetek túlnyomó többségében intenzív hitelkiáramlással jártak együtt. Cerutti et al. (2017) hasonló eredményre jutott: a nemzetközi lakásár boom-időszakok csupán mintegy ötödét azonosította túlzott hitelkiáramlás nélküli egyensúlytalanságként. Érdemes megjegyezni, hogy a szerzők által vizsgált ingatlanpiaci boom-időszakok mintegy hatvan százalékában nemcsak a jelzáloghitelezésben, de a háztartási hitelek tágabb körében is tapasztalható volt az intenzív hitelkiáramlás. Érdemes megjegyezni, hogy az ingatlanpiaci amplifikációs mechanizmusok nem feltétlen működnek hasonló erősséggel az eszközpiacok mindegyikén. Schularick és Taylor (2012) a hitelállomány-növekedést a legsikeresebb előrejelző változóként azonosította, ugyanakkor a tőzsdei árak változásával való interakcióját nem találta lényegesnek a pénzügyi krízisek bekövetkezési valószínűségének növekedésében. A szakirodalom alapján a bankrendszeri válságok bekövetkezési valószínűségét legsikeresebben közelítő makrováltozók jellemzően az adósságszolgálati terheket legjobban megragadó aggregátumok, illetve a valamivel korábban megfigyelhető hitelkiáramlási dinamikát és szintet megragadó változók (Drehmann - Juselius 2014; Drehmann et al. 2017).

Bár a túlzott hitelkiáramlás súlyos pénzügyi kríziseket okozhat, a reálgazdaságot fenntartható módon támogató hitelezés nemzetgazdasági szinten fontos tényező. Gorton és Ordoñez (2016) nemzetközi mintán olyan időszakokat hasonlít össze, melyek mindegyikében a GDP arányában egy bizonyos növekedési ütem felett bővült a hitelállomány, azonban egyes időszakok pénzügyi krízissel, míg más hasonló időszakok anélkül értek véget. A gyorsan bővülő, de krízis nélkül véget érő időszakokban mind a fejlett, mind a feltörekvő országokban gyorsabb volt az átlagos gazdasági növekedés, a beruházások átlagos növekedése és a termelékenység javulása (munka és teljes tényezőtermelékenység tekintetében is). Ennek megfelelően kiemelten fontos, hogy a makroprudenciális politika egyéb indikátorok és szempontok figyelembe vételével azonosítani tudja a fundamentálisan kevésbé megalapozott dinamikus időszakokat. 


\section{Az adósságfék-szabályok, mint a túlzott lakossági eladósodottságot megakadályozó makroprudenciális eszközök}

\subsection{Az adósságfék-szabályok hatásmechanizmusa}

Az adósságfék-szabályok két fő típusa a felvehető maximális hitelösszeget, illetve az adósok maximálisan vállalható törlesztési terhét korlátozó mutatók. Az úgynevezett hitelfedezeti mutató (loan to value, LTV) a fedezetként felajánlott eszköz forgalmi értékének arányában felvehető hitelösszeg maximumát határozza meg. Az adósságfék-jellegű előírások másik fő csoportja az úgynevezett jövedelemarányos hitelkorlát (loan to income, LTI), illetve a jövedelemarányos törlesztőrészlet (payment to income, PTI) szabályozás. Az előbbi szabály az adós által felvehető maximális hitelösszeget szabja meg az adós rendszerint éves szinten stabilan rendelkezésre álló jövedelme alapján, míg az utóbbi a maximálisan vállalható havi törlesztőrészletek mértékét korlátozza az adós havi jövedelme alapján.

Az adósságfék-előírások leginkább a túlzott háztartási hitelezést fogják vissza. A háztartási szektor mellett elméletileg lehetséges lenne ezen makroprudenciális eszközök kiterjesztése a vállalati hitelezésre is, azonban a mutatók kalibrációs nehézségei miatt ilyen alkalmazás nem terjedt el. A vállalatok esetében ugyanis nem egyértelmű a stabilan rendelkezésre álló jövedelem definiálása, illetve jelentős nehézségekbe ütközhet a fedezetként felajánlott eszközök forgalmi értékének pontos meghatározása is.

A hitelfedezeti és jövedelemalapú előírások jelentősen mérsékelhetik az ingatlanárak és a lakossági hitelezés ciklikusságát. Az előírások mind a hitelkeresletre, mind pedig a hitelkínálatra hatnak. A hitelfedezeti limit elsősorban a hitelnyújtók oldalán korlátozza a maximálisan adható hitelösszeget, az esetleges ingatlanár-korrekciók okozta potenciális veszteségek megelőzésére, a jövedelemalapú előírások pedig az adósok esetében korlátozzák a maximálisan vállalható törlesztési terhek vagy a maximálisan felvehető hitelösszeg mértékét. A két mutatóra vonatkozó korlátozás együttesen visszafogja a túlzott lakossági hitelezést, és arra ösztönözi a bankokat, hogy a hitelezési feltételek lazítása helyett a termékek árában és többletszolgáltatások nyújtásával versenyezzenek. A szabályozások ezáltal célzottan járulnak hozzá a túlzott lakossági eladósodással járó rendszerkockázatok csökkentéséhez, és támogatják a hitelezés fenntartható szerkezetű bővülését (ESRB 2014). 


\section{2. táblázat}

Az adósságfék-szabályok transzmissziója

\begin{tabular}{|c|c|c|c|c|}
\hline & $\begin{array}{c}\text { Közvetlen } \\
\text { alkalmazkodási } \\
\text { csatornák }\end{array}$ & $\begin{array}{l}\text { Bankrendszeri } \\
\text { hatások }\end{array}$ & $\begin{array}{l}\text { Bankrendszeren } \\
\text { kívüli hatások }\end{array}$ & Aggregált hatások \\
\hline \multirow{3}{*}{$\begin{array}{l}\text { HFM } \downarrow \\
\text { JTM } \downarrow\end{array}$} & $\begin{array}{l}\text { Szabályozói } \\
\text { arbitrázs }\end{array}$ & $\begin{array}{c}\text { A külföldi hitelezés } \\
\text { szerepe } \\
\text { növekedhet }\end{array}$ & $\begin{array}{c}\text { A nem banki } \\
\text { intézmények } \\
\text { hitelezésben } \\
\text { betöltött szerepe } \\
\text { növekedhet }\end{array}$ & \multirow{3}{*}{$\begin{array}{l}\text { A hitelezési ciklus } \\
\text { simításával, a PD- } \\
\text { és LGD-értékek } \\
\text { csökkenésével } \\
\text { a bankrendszer } \\
\text { ellenállóképessé- } \\
\text { ge növekszik, } \\
\text { kisebb a válságot } \\
\text { követő visszaesés, } \\
\text { gyorsabb } \\
\text { a reálgazdasági } \\
\text { kilábalás }\end{array}$} \\
\hline & Hitelpiac & $\begin{array}{c}\text { Hitelkereslet } \downarrow \\
\text { Hitelkínálat } \downarrow\end{array}$ & \multirow[b]{2}{*}{$\begin{array}{l}\text { Ingatlanárak } \\
\text { kilengései } \\
\text { mérséklődnek }\end{array}$} & \\
\hline & Várakozások & $\begin{array}{l}\text { Szigorúbb } \\
\text { kockázatkezelés } \\
\text { PD } \downarrow \text { és LGD } \downarrow\end{array}$ & & \\
\hline
\end{tabular}

Forrás: MNB (2016)

Az adósságfék-szabályok a hitelnyújtók és az adósok sokkellenálló képességét egyszerre növelik, és ezáltal mérséklik egy potenciális pénzügyi válság negatív hatását. A hitelfedezeti előírás egyrészt elősegíti, hogy az ingatlanárak csökkenése esetén is kielégíthetők legyenek a banki követelések a biztosított fedezetek igénybevételével, másrészt a jövedelemalapú előírások segítik azt, hogy az adósok számára valamekkora mozgástér még rendelkezésre álljon a törlesztési terhek emelkedése vagy jövedelmük csökkenése esetén. Az adósságfék-szabályokat emellett anticiklikus módon a pénzügyi ciklus aktuális állapota szerint érdemes kalibrálni. Eszerint a szabályokat túlzott kockázatvállalással jellemezhető időszakokban érdemes lehet szigorítani, míg pénzügyi válságok esetén enyhíteni, noha a jövedelemalapú előírások a lakossági jövedelmek kisebb változékonysága miatt a ciklus teljes egészében effektívebbek lehetnek, mint a hitelfedezeti szabályozás (Szombati 2017). Emellett erőteljes hitelpiaci és ingatlanár-túlfütöttség esetén az ingatlanárak a lakossági jövedelmeknél és megtakarításoknál gyorsabban nőnek, így a hitelfedezeti mutatóra vonatkozó előírás fenntartása változatlan szinten is egyre erősebb korlátot szab a lakáspiaci túlzott hitelezés kialakulásának (ESRB 2014), ugyanakkor a túlfütöttség erőteljesebb korlátozása érdekében szükséges lehet a korlát szintjének anticiklikus változtatása is.

A szúkebb makroprudenciális célrendszernél tágabb perspektívában az adósságfék-szabályok kedvező fogyasztóvédelmi hatását is érdemes értékelni. Az adósságfék-szabályoknak a makroprudenciális mellett jelentős fogyasztóvédelmi szerepe is van, hiszen azok nemcsak a háztartási szegmens egészének túlzott hitelezését képesek korlátozni, hanem minden egyes érintett hitelfelvevőt is védenek a túlzott eladósodottságtól. Az ügyletszintű előírásnak köszönhetően mérséklődhet annak valószínűsége, hogy a válság után tapasztalt, nemteljesítő adósok helyzetéből fakadó szociális problémák újra felmerüljenek. 
Az adósságfék-szabályok kalibrációja során szükséges a szabályozói arbitrázs lehetőségének korlátozása is. Nouy (2017) a szabályozói arbitrázs² három típusát különbözteti meg. Ezek egyrészt az eltérő szabályozás alá eső joghatóságokon átnyúló üzleti tevékenységek, másrészt az eltérő szabályozás alá eső szektorokon átnyúló üzleti tevékenységek, végül a szabályozáson belül felfedezett kiskapuk kihasználása. Az első két típus múködését az adósságfék-szabályok esetében a 2. táblázat illusztrálja. Ha az adósságfék-szabályok hatálya a hazai banki intézményekre korlátozódik, akkor a limitek szigorításának hatására a hazai bankok hitelezését helyettesíthetik külföldi intézmények határon átnyúló, vagy fióktelepi hitelezéssel, illetve nem-banki pénzügyi vállalkozások és egyéb nem-banki hitelezéssel foglalkozó intézmények. A harmadik típusú szabályozási arbitrázst az 5.3. fejezet vizsgálja részletesebben.

\subsection{Az adósságfék-előírások hatásossága a nemzetközi tapasztalatok alapján}

Az adósságfék-szabályok a kezdeti, egyelöre viszonylag korlátozottan rendelkezésünkre álló tapasztalatok szerint hatásosan csökkentik a túlzottan gyors hitelkiáramláshoz kapcsolódó kockázatokat, és a hitelezés által fútött ingatlanpiaci áremelkedésre is mérséklő hatással lehetnek. A 2007-2008-as globális válságot megelőzően nem volt széles körben elterjedt az adósságfék-szabályok aktív és jogszabályi szintű alkalmazása. A válságot követő években azonban világszerte egyre népszerübb szabályozói eszköz lett, melyet a makroprudenciális szabályozás jelentőségének tudatosodása mellett a fejlett gazdaságokra jellemző alacsony kamatkörnyezetben fellépő aktuális rendszerkockázati problémák (például intenzív, akár erős regionális heterogenitással megvalósuló ingatlanár-emelkedés) is motiválhatnak. Az adósságfék-szabályok hatásosságának becslése azonban kihívást jelent, mivel a bevezetését követően csak viszonylag rövid idő telt el, és több országban a hitelezési aktivitás még az egyensúlyi szint alatt bővül a válságot követően, ami korlátozza a fejlett mérési módszerek alkalmazhatóságát. Másfelől a makroprudenciális politika alkalmazása során - természetéből fakadóan - annak rövid távú költségei azonnal felléphetnek, miközben előnyei (például egy jövőbeli válság jelentős negatív hatásainak érdemi mérséklése) időben jóval később és nehezebben mérhető módon jelenik meg.

Ennek ellenére az eddigi empirikus tapasztalatok alapján az adósságfék-szabályok az egyik legígéretesebb szabályozói eszköznek bizonyulnak (3. táblázat). Ugyanakkor az eredmények arra is felhívják a figyelmet, hogy a vizsgálati módszereken túlmenően az eltérő gazdaságokban és időszakokon a különböző adósságfék-eszközök hatásossága változhat egyes szabályozói célváltozókra gyakorolt hatásukban.

\footnotetext{
${ }^{2}$ A szabályozói arbitrázs alatt értve a bankok üzleti magatartásának változását a szabályozás hatásainak megkerülésére a célzott kockázat mérséklése nélkül.
} 


\section{3. táblázat}

\section{A PTI- és LTV-szabályok hatásait vizsgáló tanulmányok}

\begin{tabular}{|c|c|c|c|}
\hline \multicolumn{4}{|c|}{ Nemzetközi mintán végzett vizsgálatok } \\
\hline $\begin{array}{l}\text { A szabályozással } \\
\text { célzott változó }\end{array}$ & $\begin{array}{l}\text { Szerző(k) (földrajzi hatókör) [egyéb részletek az } \\
\text { eredményváltozóról] }\end{array}$ & $\begin{array}{l}\text { JTM } \\
\text { (\& LTI) }\end{array}$ & HFM \\
\hline \multirow{5}{*}{$\begin{array}{l}\text { Lakás- vagy } \\
\text { jelzáloghitel- } \\
\text { állomány } \\
\text { (növekedés) }\end{array}$} & Kuttner és Shim 2013 (57 ország világszerte) & $\begin{array}{l}\text { szignifikáns } \\
\text { és lényeges }\end{array}$ & $\begin{array}{c}\text { nem } \\
\text { szignifikáns }\end{array}$ \\
\hline & McDonald 2015 (17 ország világszerte) & szignifikáns & szignifikáns \\
\hline & Akinci és Olmstead-Rumsey 2015 (57 ország világszerte) & $\begin{array}{l}\text { szignifikáns } \\
\text { és lényeges }\end{array}$ & $\begin{array}{l}\text { szignifikáns } \\
\text { és lényeges }\end{array}$ \\
\hline & $\begin{array}{l}\text { Jácome és Mitra } 2015 \text { (5 kelet-ázsiai és kelet-európai } \\
\text { ország) }\end{array}$ & n.a. & szignifikáns \\
\hline & Morgan et al. 2015 (10 ország Ázsiában) & n.a. & szignifikáns \\
\hline \multirow{3}{*}{$\begin{array}{l}\text { Magánszektornak } \\
\text { nyújtott hitelek } \\
\text { (növekedés, reál) }\end{array}$} & Lim et al. 2011 (49 ország világszerte) & szignifikáns & szignifikáns \\
\hline & Geršl és Jašová 2014 (11 ország Középkelet-Európában) & \multicolumn{2}{|c|}{ szignifikáns } \\
\hline & Cerutti et al. 2017 (119 ország világszerte) & szignifikáns & szignifikáns \\
\hline \multirow{7}{*}{$\begin{array}{l}\text { Lakásár- } \\
\text { növekedés }\end{array}$} & Crowe et al. 2013 (21 ország világszerte) & szignifikáns & $\begin{array}{c}\text { nem } \\
\text { szignifikáns }\end{array}$ \\
\hline & $\begin{array}{l}\text { Vandenbussche et al. } 2015 \text { (16 ország Középkelet és } \\
\text { Dél-Kelet-Európában) }\end{array}$ & $\begin{array}{l}\text { nem } \\
\text { szignifikáns }\end{array}$ & $\begin{array}{c}\text { nem } \\
\text { szignifikáns }\end{array}$ \\
\hline & Kuttner és Shim 2013 (57 ország világszerte) & $\begin{array}{l}\text { nem } \\
\text { szignifikáns }\end{array}$ & szignifikáns \\
\hline & McDonald 2015 (17 ország világszerte) & \multicolumn{2}{|c|}{ szignifikáns } \\
\hline & Akinci és Olmstead-Rumsey 2015 (57 ország világszerte) & $\begin{array}{l}\text { szignifikáns } \\
\text { és lényeges }\end{array}$ & $\begin{array}{l}\text { szignifikáns } \\
\text { és lényeges }\end{array}$ \\
\hline & Cerutti et al. 2017 (119 ország világszerte) & $\begin{array}{l}\text { nem } \\
\text { szignifikáns }\end{array}$ & $\begin{array}{c}\text { nem } \\
\text { szignifikáns }\end{array}$ \\
\hline & Carreras et al. 2016 (19 OECD-ország) & szignifikáns & szignifikáns \\
\hline \multicolumn{4}{|c|}{ Egyedi országok vizsgálata } \\
\hline Késedelmi arány & Baek et al. 2013 (Dél-Korea) & szignifikáns & szignifikáns \\
\hline \multirow{7}{*}{$\begin{array}{l}\text { Lakás- vagy } \\
\text { jelzáloghitel- } \\
\text { állomány }\end{array}$} & $\begin{array}{l}\text { Igan és Kang } 2011 \text { (Dél-Korea) [nem nagyvárosi } \\
\text { területeken mért háztartási hitelnövekedés] }\end{array}$ & szignifikáns & szignifikáns \\
\hline & Kim 2013 (Dél-Korea) [negyedéves növekedés] & szignifikáns & $\begin{array}{l}\text { szignifikáns } \\
\text { és lényeges }\end{array}$ \\
\hline & Lee 2013 (Dél-Korea) [reálszint] & $\begin{array}{l}\text { nem } \\
\text { szignifikáns }\end{array}$ & $\begin{array}{c}\text { nem } \\
\text { szignifikáns }\end{array}$ \\
\hline & $\begin{array}{l}\text { Price } 2014 \text { (Új-Zéland) [országos növekedés, } \\
\text { kontrafaktuális becslés] }\end{array}$ & n.a. & szignifikáns \\
\hline & $\begin{array}{l}\text { Wong et al. } 2014 \text { (Hong Kong) [becsült kínálat és } \\
\text { kereslet] }\end{array}$ & n.a. & szignifikáns \\
\hline & Neagu et al. 2015 (Románia) [növekedés] & \multicolumn{2}{|c|}{ szignifikáns } \\
\hline & $\begin{array}{l}\text { Kuncl } 2016 \text { (Kanada) [szint, valamint a hatás } \\
\text { a rezidenciális beruházásra] }\end{array}$ & n.a. & szignifikáns \\
\hline
\end{tabular}




\begin{tabular}{|c|c|c|c|}
\hline \multicolumn{4}{|c|}{$\begin{array}{l}\text { 3. táblázat } \\
\text { A PTI- és LTV-szabályok hatásait vizsgáló tanulmányok }\end{array}$} \\
\hline \multirow{6}{*}{ Lakásár } & Craig és Hua 2011 (Hong Kong) [negyedéves növekedés] & n.a. & $\begin{array}{l}\text { szignifikáns } \\
\text { és lényeges }\end{array}$ \\
\hline & $\begin{array}{l}\text { Igan és Kang } 2011 \text { (Dél-Korea) [növekedés, nagyvárosi } \\
\text { körzet] }\end{array}$ & $\begin{array}{l}\text { nem } \\
\text { szignifikáns }\end{array}$ & szignifikáns \\
\hline & Kim 2013 (Dél-Korea) [negyedéves növekedés] & szignifikáns & $\begin{array}{l}\text { szignifikáns } \\
\text { és lényeges }\end{array}$ \\
\hline & Lee 2013 (Dél-Korea) [reálszint] & $\begin{array}{l}\text { nem } \\
\text { szignifikáns }\end{array}$ & $\begin{array}{l}\text { nem } \\
\text { szignifikáns }\end{array}$ \\
\hline & $\begin{array}{l}\text { Price } 2014 \text { (Új-Zealand) [éves növekedés, kontrafaktuális } \\
\text { becslés] }\end{array}$ & n.a. & szignifikáns \\
\hline & Kronick 2015 (Kanada) & n.a. & $\begin{array}{c}\text { nem } \\
\text { szignifikáns }\end{array}$ \\
\hline
\end{tabular}

Megjegyzés: A SÁRGA cellák a tanulmányok által kimutatott szignifikáns hatásokat jelölik, a FEHÉR cellák a nem-szignifikáns eredményeket, a NARANCS cellák azokat a becsléseket, amelyek esetében a modellezett szabályozói intervenciók kvantitativ hatása a többi vizsgált szabályozó beavatkozáshoz hasonlítva (például tökeeszközök, fiskális eszközök stb.) kiemelkedö. A SZÜRKE cellák az adott vizsgálatba be nem vont eszköz(öke)t jelölik. Azok a cellák, melyek nincsenek középen elválasztva, olyan vizsgálatokat jelölnek, melyben a két különböző típusú eszköz hatását nem elkülönítve vizsgálják.

Forrás: Fáykiss et al. (2017)

A szabályozás reálgazdasági költségeinek és hasznainak becslése sajnos a korlátozott tapasztalatok miatt még meglehetősen ritka a nemzetközi vizsgálatokban. Az egyik legkiterjedtebb mintán Boar et al. (2017) elemzi a makroprudenciális eszközök hatását a GDP hosszú távú volatilitására és növekedési rátájára. A szerzők nem tesznek különbséget a különböző ciklikus típusú makroprudenciális eszközök között, így az adósságfék-szabályok hatását és például a tőkepufferek hatását egyetlen becslésben mérik. Eredményeik alapján megállapítható, hogy a ciklikus makroprudenciális eszközök alkalmazása általánosságban csökkenti a kibocsátás hosszú távú volatilitását, és nem korlátozza érdemben a növekedést, sőt akár pozitivan is hathat rá. Azonban az átlagnál pénzügyileg fejlettebb országokban a szabályok előző kedvező tulajdonságai mérsékeltebbek lehetnek.

\section{Az adósságfék-szabályok alkalmazása Európában}

Az adósságfék-előírások használata egyre elterjedtebb Európán belül is. Az alkalmazó országok körét tekintve megfigyelhető a keletközép-európai és az északi tagállamok túlsúlya, míg az eurozóna magországainak ilyen jellegú szabályozói aktivitása csekélynek mondható (MNB 2016). Az egyes nemzeti szabályozások kalibrációját tekintve megemlítendő, hogy míg a hitelfedezeti mutató (HFM) kialakítása nagyrészt azonos az országok között, addig az adósok törlesztési képességének figyelembe vételére két fő mutatócsoport azonosítható. Egyrészt a jövedelemarányos 
törlesztőrészlet (JTM) típusú mutatók, amelyek a havi törlesztőrészletek maximális mértékét korlátozzák az adósok jövedelméhez viszonyítva, másrészt pedig az LTI (loan to income) -mutatók, amelyek a maximálisan felvehető hitelösszeget határozzák meg az adósok éves jövedelme alapján (3. ábra).

\section{3. ábra \\ Adósságfék jellegű előírások az Európai Gazdasági Térség országaiban}

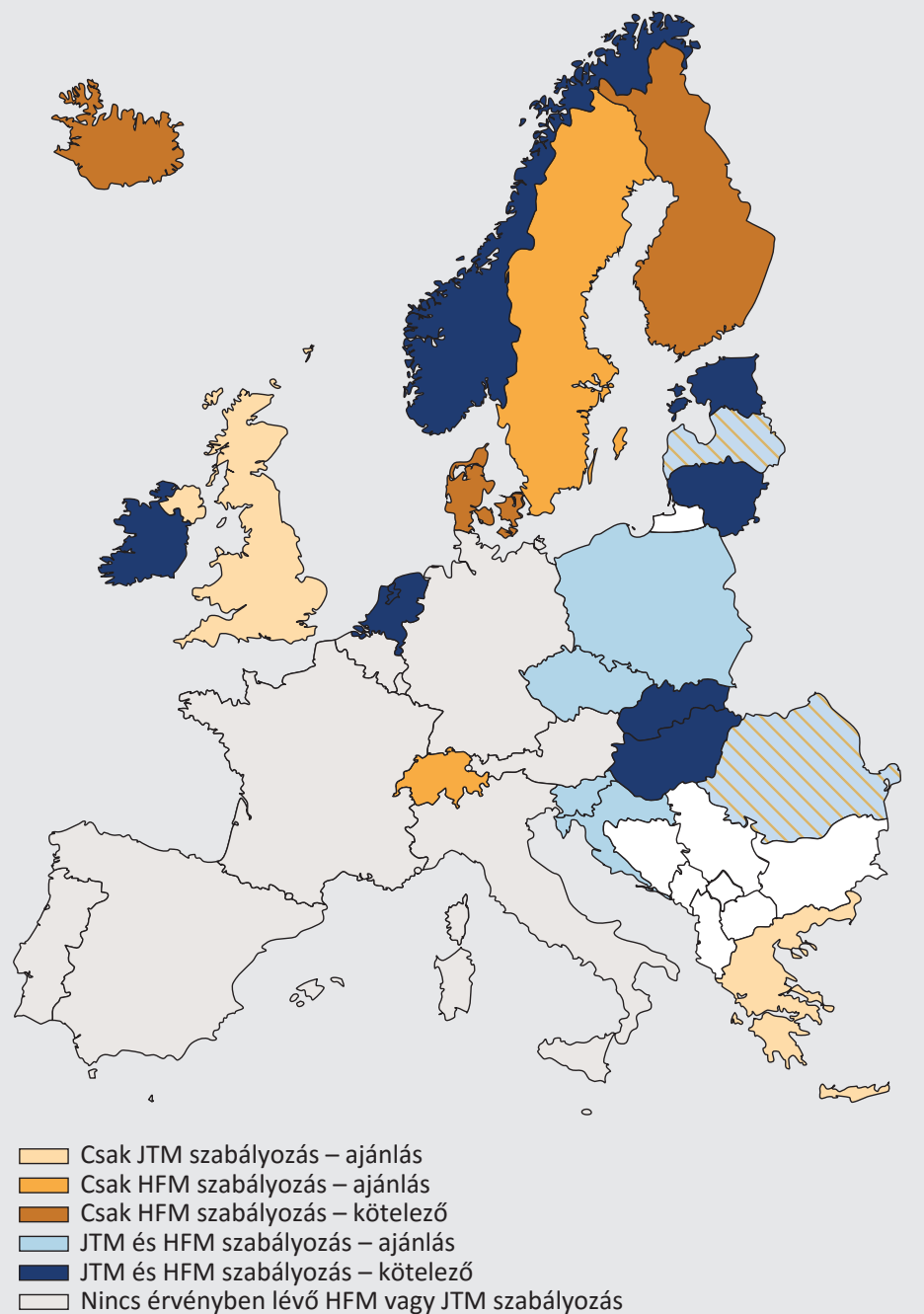

Megjegyzés: Románia és Lettország esetében a HFM-szabályozás kötelezö, a JTM-limit pedig ajánlás formájában került meghatározásra.

Forrás: MNB (2017b) 
A limitek egyes régiókban való alkalmazása a következőképp foglalható össze:

- Keletközép-európai országok: Magyarország mellett Szlovákia alkalmaz együttesen kötelező HFM- és JTM-korlátokat, míg a többi régiós országban jellemzően csak ajánlást fogalmaztak meg (Csehország, Lengyelország, Szlovénia, Horvátország) vagy csak a HFM tekintetében alkottak kötelező rendelkezéseket, a JTM-limiteket - kötelező HFM-előírás ellett - ajánlás formájában kezelve (Románia).

- Északi országok: Svédországban ajánlás, Dániában, Finnországban és Izlandon jogszabály formájában alkalmaznak HFM-előírásokat. Lettországban a kötelező HFM mellett a JTM-re vonatkozó limitet ajánlás, Észtországban és Litvániában kötelező előírás formájában határozzák meg, illetve Norvégia a kötelező HFM mellett kötelező LTI-mutatót vezetett be.

- Déli országok: E tagállamok közül egyedül Cipruson van kötelező jellegű JTMés HFM-szabályozás, míg Görögországban a JTM-re vonatkozóan adtak csak ki ajánlást.

- Egyéb európai országok: Hollandiában kötelező HFM- és JTM-előírást, Írországban kötelező érvényú LTI- és HFM-előírásokat alkalmaznak, míg az Egyesült Királyságban csak az adósok által maximálisan felvehető hitelösszeget szabályozzák azok éves jövedelméhez képest, nem kötelező ajánlás formájában.

Az EU-ban bevezetett adósságfékek küszöbértékeinek látszólagos közelsége ellenére azok összehasonlíthatóságát jelentősen nehezítik a rájuk vonatkozó eltérő részletszabályok. A nemzeti hatáskörben maradt adósságfék-szabályok kapcsán a jövedelemarányos törlesztőrészlet tekintetében az egyes tagállamok eltérő módon határozzák meg például a figyelembe veendő adósságszolgálat és a jövedelem komponenseit (például a létfenntartáshoz szükséges költségek vonatkozásában), az adóstársak és magasabb jövedelmúek kezelésének szabályait, a de minimis korlátokat, a bullet és változó kamatozású hitelek beszámíthatóságát. Több tagállam PTI-mutató helyett LTI-mutatót használ, mely az éves jövedelem arányában a maximálisan felvehető hitelösszeget limitálja. A hitelfedezeti mutató tekintetében a forgalmi érték megállapítására vonatkozóan eltérő rendelkezések vannak érvényben több országban. Ennek megfelelően a jövedelmi kifeszítettségre és a fedezetek igénybevételére vonatkozó előírások nemzetközileg nehezen összehasonlíthatók. Ezért bár a 4. táblázatban látható szintek gyakran közel esnek egymáshoz, a szabályozói limitek szintje alapján nehézkes az adott előírás „szigorúságát” meghatározni. 


\begin{tabular}{|c|c|c|c|}
\hline \multicolumn{4}{|c|}{$\begin{array}{l}\text { 4. táblázat } \\
\text { Adósságfék-szabályok Európában }\end{array}$} \\
\hline Ország & PTI és LTI* & LTV & Megjegyzés / kivételek \\
\hline $\mathrm{CH}$ & - & $90 \%$ & \\
\hline $\mathrm{CY}$ & $80 \%$ & $80 \%$ & $\begin{array}{l}\text { PTI: } 65 \% \text { deviza hitelekre } \\
\text { LTV: elsődleges lakóhelyre, egyébként 70\% }\end{array}$ \\
\hline $\mathrm{CZ}$ & $\begin{array}{c}\text { 40\% PTI, } \\
\text { 8-szoros LTI }\end{array}$ & $80 \%$ & LTV: a hitelkiáramlás 15\%-a 90\%-os limit mellett történhet \\
\hline DK & - & $95 \%$ & \\
\hline $\mathrm{EE}$ & $50 \%$ & $85 \%$ & $\begin{array}{l}\text { LTI: a hitelkiáramlás } 80 \% \text {-ára, ha a kamat alacsony, akkor } \\
\text { stresszelt kamatszinttel } \\
\text { LTV: a hitelkiáramlás } 85 \% \text {-ára, } 90 \% \text { is lehet állami } \\
\text { hitelgaranciával }\end{array}$ \\
\hline $\mathrm{FI}$ & - & $90 \%$ & LTV: 95\% első lakásvásárlóknak \\
\hline GR & $30-40 \%$ & - & \\
\hline $\mathrm{HU}$ & $50 \%$ & $80 \%$ & $\begin{array}{l}\text { PTI: } 10 \text { és } 60 \% \text { között differenciált jövedelemtől, } \\
\text { devizanemtől függően } \\
\text { LTV: devizahitelre vagy gépkocsi-lízingre szigorúbb 30\%-ig }\end{array}$ \\
\hline IE & $\begin{array}{l}\text { 3,5-szeres } \\
\text { LTI }\end{array}$ & $90 \%$ & $\begin{array}{l}\text { LTI: a hitelkiáramlás } 80 \% \text {-ára első lakásvásárlóknak és 90\%- } \\
\text { ára nem első lakást vásárlóknak } \\
\text { LTV: a hitelkiáramlás } 85 \% \text {-ára }\end{array}$ \\
\hline IZ & - & $85 \%$ & LTV: 90\% első lakásvásárlóknak \\
\hline LT & - & $90 \%$ & LTV: $95 \%$ is lehet állami hitelgaranciával \\
\hline LV & $40 \%$ & $85 \%$ & $\begin{array}{l}\text { PTI: a hitelkiáramlás 5\%-a } 60 \% \text {-os limit mellett történhet, } \\
50 \% \text {-os kamatstressz-korlátnak is meg kell felelni }\end{array}$ \\
\hline MT & - & $70 \%$ & $\begin{array}{l}\text { LTV: a 35\%-os kockázati súlyú háztartási jelzáloghitel } \\
\text { kitettségek esetén }\end{array}$ \\
\hline $\mathrm{NL}$ & - & $100 \%$ & \\
\hline NO & 5-szörös LTI & $85 \%$ & $\begin{array}{l}\text { LTI: a hitelkiáramlás 90-92\%-ára régiótól függően } \\
\text { LTV: a hitelkiáramlás 90-92 \%-ára régiótól függően, 70\% } \\
\text { ingatlanfedezetű hitelkeret, HELOC típusú termékeknél, 60\% } \\
\text { az oslói nem elsődleges lakásokra }\end{array}$ \\
\hline $\mathrm{PL}$ & $40 \%$ & $\begin{array}{l}\text { 80\% háztartási, } \\
75 \% \text { kereskedelmi } \\
\text { ingatlanhitelekre }\end{array}$ & $\begin{array}{l}\text { PTI: } 50 \% \text { magasabb jövedelmű hitelkérelmezőnél } \\
\text { LTV: } 90 \text {, illetve } 80 \% \text {-ig emelhető, ha a } 80 \text {, illetve } 75 \% \text { feletti } \\
\text { összegre megfelelő fedezet vagy garancia áll rendelkezésre }\end{array}$ \\
\hline RO & - & $\begin{array}{l}85 \% \text { lakáscélú } \\
\text { hitelekre, } 75 \% \\
\text { fogyasztási } \\
\text { hitelekre }\end{array}$ & $\begin{array}{l}\text { LTV: devizahitelekre } 80 \text { és } 60 \% \text { között a devizanem és az } \\
\text { FX-kockázat fedezésétől függően, 95\% állami hitelgaranciával }\end{array}$ \\
\hline SE & - & $85 \%$ & \\
\hline SI & $50 \%$ & $80 \%$ & $\begin{array}{l}\text { PTI: } 67 \% \text { a magasabb jövedelmű hitelkérelmezőknél, de csak } \\
\text { a jövedelem egy részét lehet a lazább korlátba beszámítani }\end{array}$ \\
\hline SK & $80 \%$ & $80 \%$ & $\begin{array}{l}\text { PTI: } 2 \text { százalékpontos kamatsokkal számítva nem fix } \\
\text { kamatozású hitelfelvételnél, } 1 \text {-szeres LTI-mutatóig } 100 \% \\
\text { LTV: a hitelkiáramlás } 40 \% \text {-a meghaladhatja } 100 \% \text {-ig, de max. } \\
\text { 10\%-a lehet } 90 \% \text { felett, illetve } 1 \text {-szeres LTI-mutatóig is } 100 \% \\
\text { az LTV-limit }\end{array}$ \\
\hline UK & $\begin{array}{l}\text { 4,5-szeres } \\
\text { LTI }\end{array}$ & - & LTI: a hitelkiáramlás 85\%-ára \\
\hline
\end{tabular}

Megjegyzés: *Ha a feltüntetett limitek LTI-szabályozásokra hivatkoznak, akkor azt külön jelezzük, egyébként PTI típusú szabályozásokra vonatkoznak a százalékos limitek.

Forrás: ESRB (2017) 
Az egyes országok által alkalmazott szabályozói eszközök tekintetében több különbség azonosítható:

- Intézményi hatály: Egyes országok (pl. Hollandia és Magyarország) esetében a szabály széles intézményi hatállyal bír, hiszen a hitelintézetek mellett a nem banki hitelnyújtókra is kiterjed, ami csökkenti a szabályozás megkerülésének lehetőségét.

- Beszámítható jövedelmek: A magyar mellett csak a ciprusi, észt és szlovák előírásokban jelenik meg szabályozott módon az adózott jövedelmek prudens igazolásának szükségessége, míg a többi, kötelező szabályozást alkalmazó ország a bankokra bízza a beszámítható jövedelmek körének meghatározását.

- Kockázati dimenziók szerinti differenciálás: Nemzetközi összehasonlításban a HFM-előírások a denomináció (Románia) vagy az ingatlan értéke (Írország) szerint tesznek különbséget, míg a JTM-előírások hasonló jellegű megbontása a magyar gyakorlaton kívül - mindeddig nem terjedt el.

Az előírások célzottságát növelendő, több EU-tagállam is alkalmaz kivételeket az adósságfék-szabályokban:

- Kedvezmények adott hitelfelvevői csoportok esetében: A kevésbé kockázatos hitelfelvevői csoportok könnyebb hitelhez jutása érdekében néhány országban lehetőséget biztosítanak valamilyen mértékben az előírást meghaladó HFM-értékkel rendelkező hitelek folyósítására (Csehország, Írország, Szlovákia). A magas ingatlanárakkal jellemezhető országokban a fiatal első lakásvásárlók otthonteremtésének támogatása érdekében pl. rájuk vonatkozóan kedvezményes HFM-előírásokat alkalmaznak (pl. Írország, Izland). Szintén az otthonteremtés elősegítése érdekében az állami támogatás mellett nyújtott lakáshitelekre vonatkozóan kedvezményes HFM-limiteket állapítottak meg a balti államokban.

- Kivételek a teljes portfólió arányában: Előfordul továbbá, hogy a szabályozók lehetővé teszik a hitelezők számára a teljes hitelfolyósítás meghatározott arányában a szabályozói limit feletti JTM- vagy jövedelemarányos hitelösszeg (LTI) -érték mellett nyújtott hitelek folyósítását, amennyiben igazolható, hogy az adósok törlesztési képessége kimagasló (pl. Észtország, Litvánia és Egyesült Királyság).

\section{Adósságfék-szabályok Magyarországon}

\subsection{A hazai adósságfék-előírások múködése}

Az MNB Európában az elsők között vezetett be kötelező érvényű, átfogó adósságfék-szabályokat. A 2015. január 1-jével életbe lépett szabályok mind az adósok jövedelmének, mind a fedezetek értékének „,kifeszítettségét” korlátozzák: az új kibocsátású háztartási hitelek összege nem haladhatja meg a fedezet értékének 80 
százalékát (hitelfedezeti mutató, HFM), az adós összegzett törlesztőrészletei pedig főszabályként legfeljebb a rendszeres és legális jövedelem 50 százalékát érhetik el (jövedelemarányos törlesztőrészlet mutató, JTM). A hazai szabályozásban a különböző kockázatok ellensúlyozása érdekében a limitek a devizahitelekre szigorúbbak, a magasabb jövedelmú hitelfelvevőkre pedig enyhébbek³ (5. táblázat).

\begin{tabular}{|c|c|c|c|c|}
\hline \multicolumn{5}{|c|}{$\begin{array}{l}\text { 5. táblázat } \\
\text { A hazai JTM- és HFM-előírások szintjei }\end{array}$} \\
\hline & & HUF & EUR & Egyéb deviza \\
\hline \multirow{2}{*}{ JTM } & 400e Ft alatti havi nettó jövedelem & $50 \%$ & $25 \%$ & $10 \%$ \\
\hline & 400e Ft vagy afeletti havi nettó jövedelem & $60 \%$ & $30 \%$ & $15 \%$ \\
\hline \multirow{2}{*}{ HFM } & Jelzáloghitelre & $80 \%$ & $50 \%$ & $35 \%$ \\
\hline & Gépjármúhitelre & $75 \%$ & $45 \%$ & $30 \%$ \\
\hline
\end{tabular}

Az adósságfék-szabályok kalibrációjakor érdemes a pénzügyi ciklus aktuális állapotát is figyelembe venni. Az előírásokat célszerű a ciklus változásának megfelelően, anticiklikus módon alakítani: míg túlhevülés idején felmerülhet, hogy szigorúbb HFM- és JTM-limitek szükségesek a túlzott eladósodás megelőzéséhez, válság idején és a hitelciklus alján, amikor a hitelezés lefagyása fenyegethet vagy bekövetkezett, általában van tér enyhíteni a szigorúbb limiteken. Az adósságfék-szabályok bevezetésének elsődleges célja - figyelembe véve a pénzügyi ciklus jelenlegi állapotát - az volt, hogy megteremtse a „féket”, amelyet a későbbiekben „behúzva” képes megelőzni a túlzott hitelkiáramlást (Szombati 2017).

A hazai adósságfék-szabályok kalibrálása széleskörű szempontrendszer lefedésével, különböző kockázati dimenziók mentén valósult meg:

i. Az adósságfék-szabályok mind az érintett hiteltermékek, mind pedig a hitelezésben részt vevő szereplők védelmét tekintve átfogónak tekinthetők. $A$ hazai adósságfék-szabályok minden háztartási hiteltermékre kiterjednek, alkalmazásuk az összes hitelnyújtó számára kötelező, így a szabályozás megkerülésének lehetősége korlátozott. A szabályok egyszerre védik a hitelezőt és a hitelfelvevőt: a JTM esetében az elsődleges cél az ügyfelek túlzott eladósodottságából eredő kockázatok csökkentése, a HFM pedig elsősorban a banki fedezett hitelekből származó potenciális veszteséget csökkenti.

ii. A devizában történő eladósodás kockázatait mindkét szabályozói eszköz esetén szigorúbb limitekkel mérsékli az előírás. Árfolyam-leértékelődés esetén mind a törlesztőrészletek, mind pedig a fedezet arányában vett tőketartozás értéke

\footnotetext{
${ }^{3}$ Ennek indokoltsága kapcsán lásd például Balás et al. (2015).
} 
nagymértékben növekedhet, melynek fedezésére a korlátoknak tartalmazniuk kell egy addicionális puffert ${ }^{4}$.

iii. A szabályozást indokolt az ügyfelek rendelkezésre álló jövedelme alapján, differenciáltan kalibrálni. Mivel a fogyasztás jellemzően a jövedelem növekedésénél kisebb mértékben nő (lásd például Hosszú 2011), ezért a magasabb jövedelem nagyobb aránya fordítható adósságszolgálatra. Balás et al. (2015) kérdőíves felmérés adatain végzett modellszámításai is alátámasztják, hogy indokolt lehetővé tenni a magasabb jövedelmü ügyfelek esetén a nagyobb mozgásteret a hitelfelvétel kapcsán, mivel az azonos JTM-szintek a magasabb jövedelmű ügyfelek esetén túlságosan szigorúak, míg alacsony jövedelemmel rendelkezők esetén túlságosan enyhék lehetnek.

iv. A prudens hitelnyújtás elősegítése érdekében az adósságfék-szabályok alkalmazásakor csak a legális, igazolható jövedelem vehető figyelembe. Mivel a legális, igazolható jövedelem más jövedelmi formáknál stabilabbnak tekinthető, ezért a JTM számításakor csak e jövedelemelemeket lehet figyelembe venni. Ez az előírás a hitelt felvenni szándékozó háztartásokat a jövedelmek bejelentésére ösztönzi, így a felelős hitelezés biztosításán túl az MNB-rendelet egyik pozitív hozadéka, hogy a gazdaság fehérítésének irányába is hat. Ezzel azonban egyes, korábban „szürke” jövedelemből, igazolás nélkül hitelhez jutó szegmensek kizárásra kerülhetnek a hitelfelvevők köréből.

\subsection{Az eddigi tapasztalatok az adósságfék-szabályok hazai alkalmazása kapcsán}

A háztartási hitelállomány esetében a közelmúltban megtörtént a hitelezési fordulat, az új háztartási hitelek kihelyezésének dinamikus növekedése pedig folytatódott. Az új hitelkihelyezések szintje a 2013. első negyedévi mélypont óta dinamikus bővülést mutat, ami 2017 első félévére már elérte a 2006 elején tapasztalt értékeket. Az utóbbi másfél évben a legnagyobb mértékű bővülést a lakáscélú jelzáloghitelek mutatták, amelyek folyósítása a 2016. év eleji 85 milliárd forintról 2017 második negyedévére 171 milliárd forintra nőtt. Ugyanezen időszak alatt a fogyasztási hitelek folyósítása is több mint kétszeresére nőtt. A fogyasztási hitelek folyósításának bővülését a személyi és áruhitelek robusztus folyósítása hajtotta, míg a szabadfelhasználású jelzáloghitelek továbbra is elhanyagolható arányt képviseltek (4. ábra).

\footnotetext{
${ }^{4}$ A szükséges puffer kalibrációja során felhasználhatók például VAR- (Value at Risk)- vagy ES- (Expected Shortfall)-elemzések. Ezek segítségével meghatározható egy olyan JTM-limit, amely biztosítja, hogy még egy szélsőséges árfolyamváltozás hatására se haladja meg a JTM értéke a forinthitelekre vonatkozó szabályozói limitet.
} 


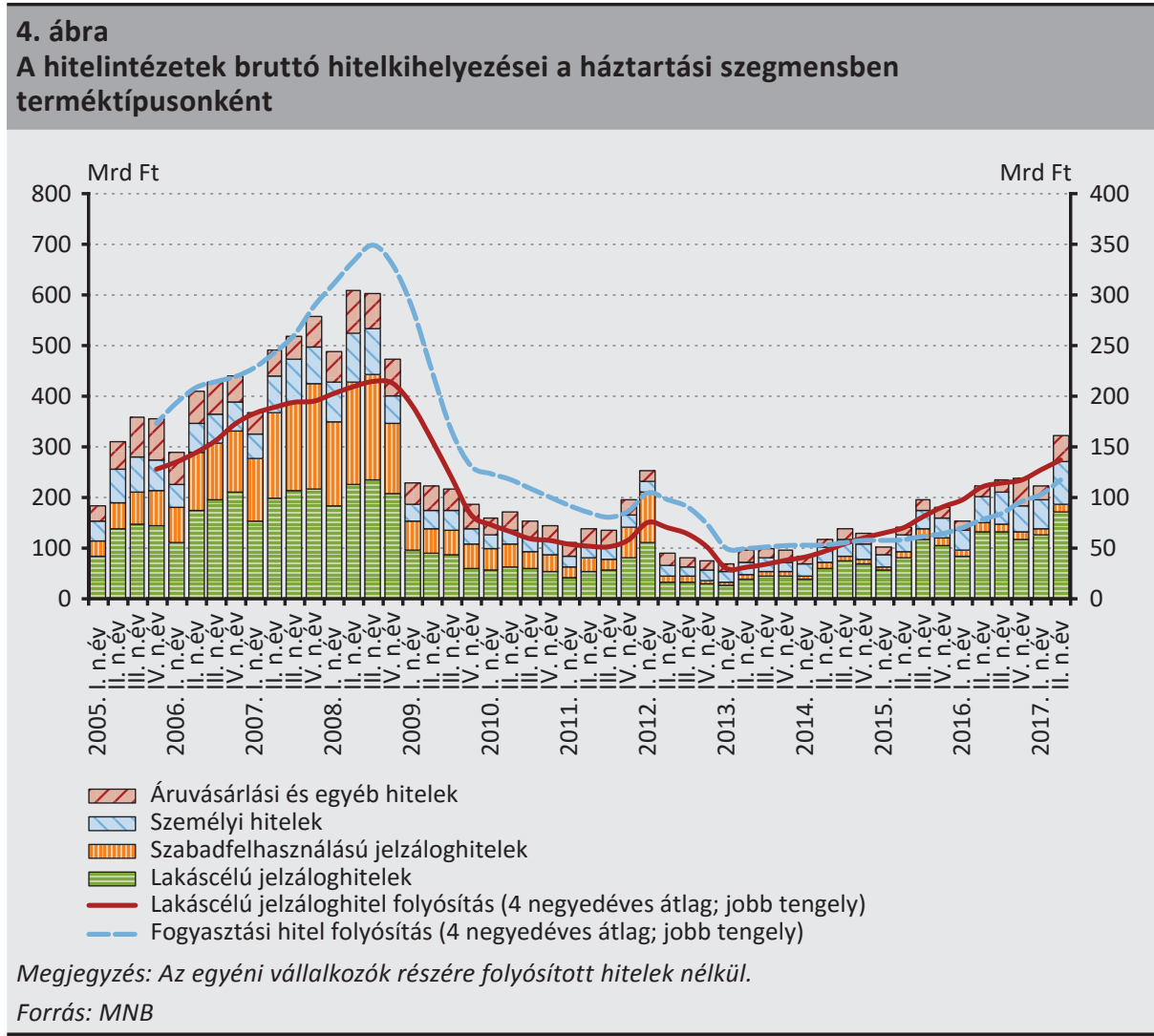

A dinamikusan bővülő hitelezési folyamatok mindeddig nem jártak együtt a lakosság jelentős eladósodásával, amit makrogazdasági szinten a negatív hitelrések is alátámasztanak ${ }^{5}$. Bár az elmúlt két és fél évben megfigyelhető volt a hitelfelvevők némileg erősebb kifeszítettsége, hiszen 2017 első félévében már a hitelek ötödét a magasabban eladósodott, 40-60 százalékos JTM-értékkel rendelkező ügyfelek részére folyósították, az még mindig mindössze 5 százalékponttal haladja meg a 2015ben megfigyelt arányt. Az idei magas reálbér-növekedés ugyanakkor lassíthatja, vagy akár meg is fékezheti a további növekedést. Eszerint, bár több hitelfelvevő esetében válhat effektívé a limit, azok továbbra sem csoportosulnak jelentősen a szabályozói korlátok közelében (5. ábra). A válság előtti évekkel szemben ugyanakkor mind a lakáscélú, mind a fogyasztási hitelek kockázatossága a bevezetett, illetve szigorított prudenciális követelmények, továbbá a piaci szereplők kockázatkerülőbb magatartása következtében jelentősen alacsonyabb (jellemzően forintdenomináció, lényegesen alacsonyabb LTV-szintek stb.). A hitelezés dinamikus bővülése ezért egyelőre az egyensúlyi hitelezés ismételt elérését szolgálja, és nem tekinthető túlzott mértékünek.

${ }^{5}$ Ennek kapcsán lásd például MNB (2017b). 


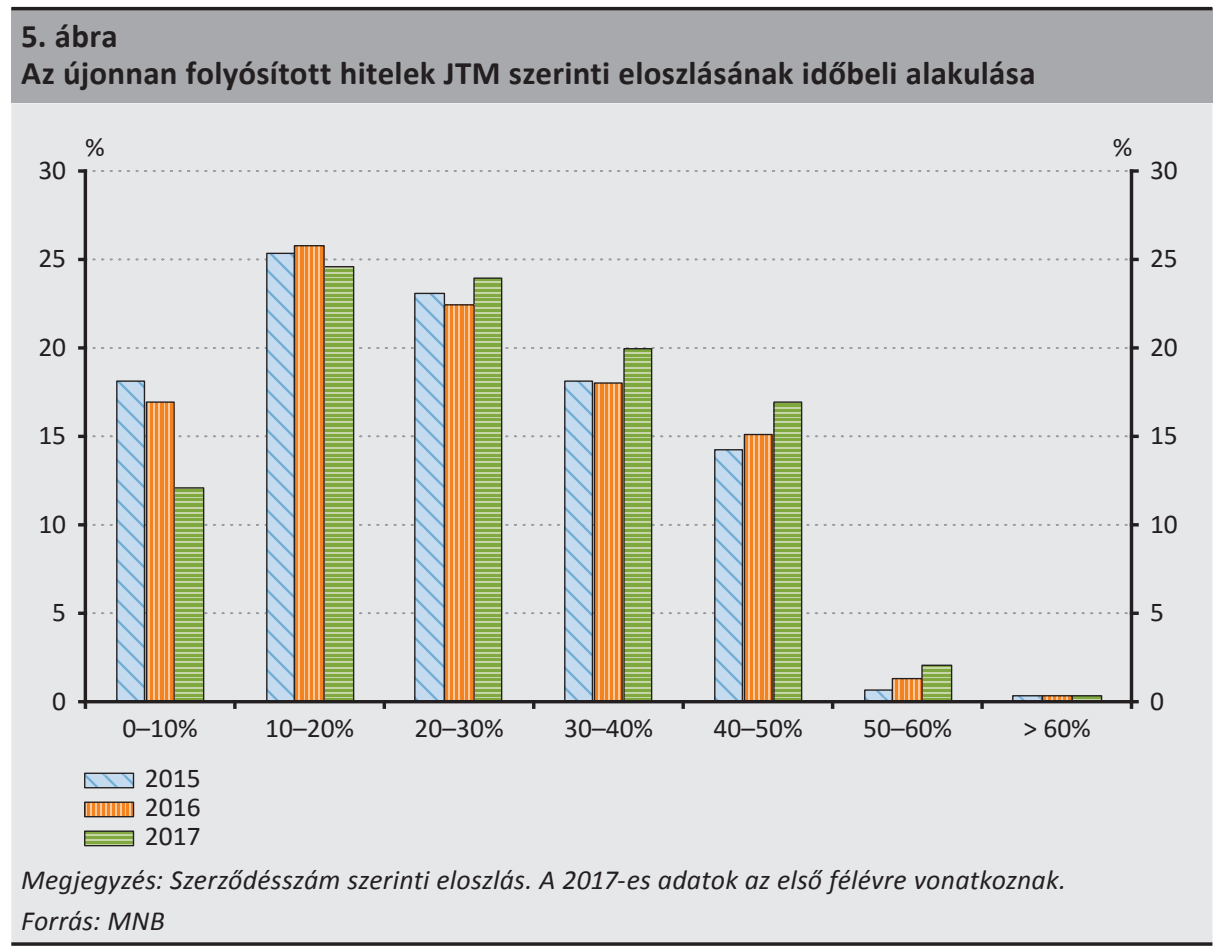

Az élénkülő lakáscélú hitelezés jelenleg Magyarországon nem fenyeget rendszerszintű adósságproblémák kialakulásával. Az elmúlt időszakban folyósított lakáscélú hitelek forintban denomináltak, futamidejük a válságot megelőzően tapasztalt 19-20 évhez képest 2017 második félévében is csak 16 évet ért el, lényegesen alacsonyabb HFM-mel rendelkeznek, és az egyes ügyletek sem csoportosulnak jelentős arányban a JTM-korlátok közelében. A lakáspiaci folyamatokhoz köthető jövőbeli adósságproblémák valószínűségét csökkenti továbbá, hogy a lakástranzakciók legfeljebb feléhez kötődik hitelfelvétel (MNB 2017a). Emellett a lakáshitelek ingatlanfedezetének megterheltsége továbbra is alacsony, bár lassan növekvő tendenciát mutat. Az emelkedő ingatlanárakkal ${ }^{6}$ és az erőteljesen bővülő lakáscélú hitelezéssel párhuzamosan az adósok nagyobb mértékben fedezik hitelfelvételből ingatlanvásárlásaikat, így a teljes lakáscélú hitelfolyósításban mind jelentősebb arányt képviselnek a forgalmi érték 70 százalékánál magasabb arányban megterhelt ingatlanfedezet mellett nyújtott hitelek. Ugyanakkor ezek aránya továbbra is messze a válság előtt tapasztalható mértékek alatt maradt (6. ábra). Emiatt a lakáshitelek elmúlt három évben tapasztalt dinamikus növekedése is lényegesen fenntarthatóbb módon valósult meg a válság előtti helyzethez képest.

\footnotetext{
${ }^{6}$ A lakáspiaci kockázatok részletesebb elemzéséért lásd az MNB Lakáspiaci jelentéseit.
} 


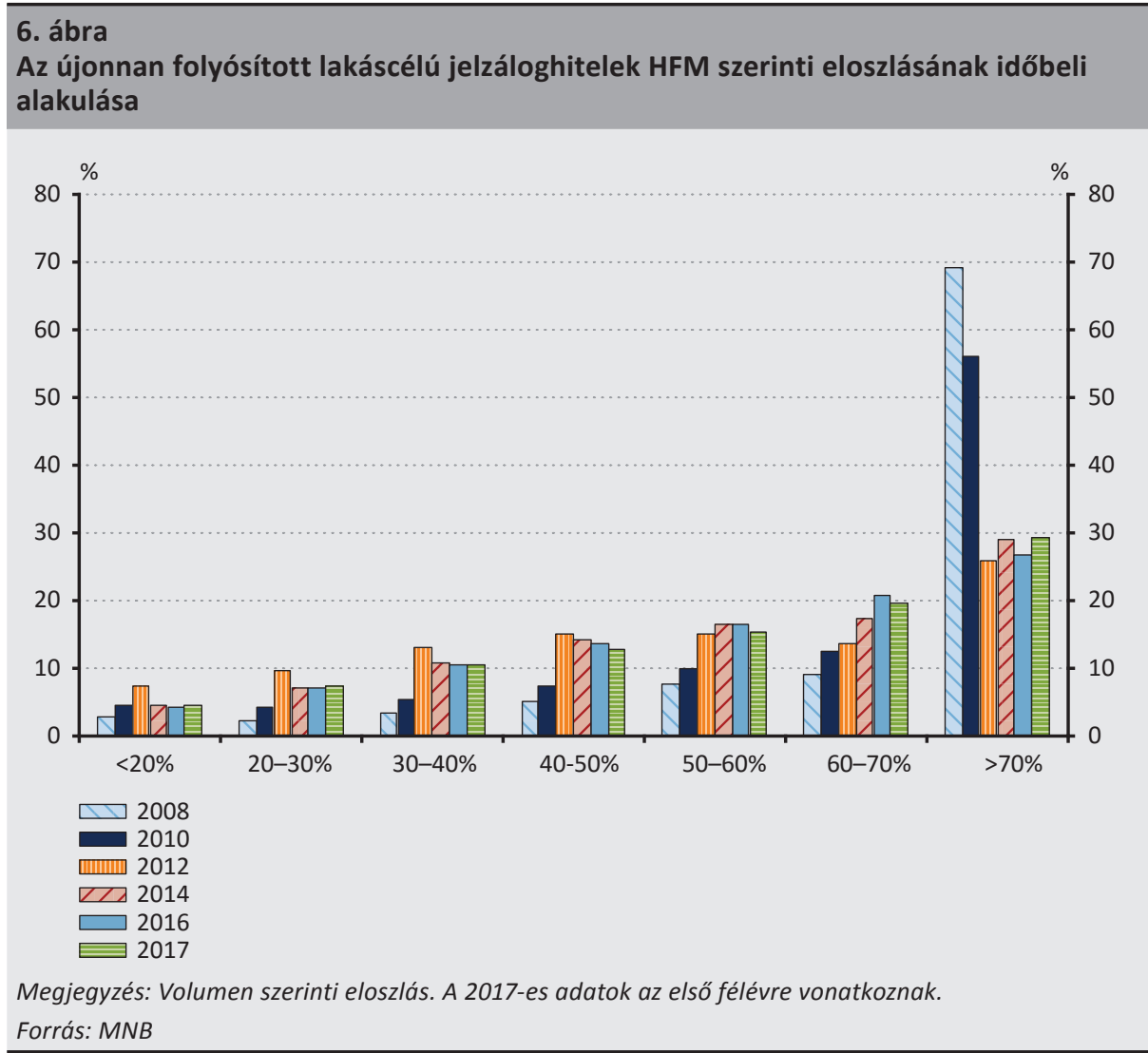

A Budapesten tapasztalható erőteljes ingatlanár-növekedés sem járt együtt egyelőre a lakosság túlzott eladósodásával. Habár a budapesti ingatlanárak az utóbbi három és fél évben a 2014 év végi szintjükhöz képest mintegy 70 százalékkal emelkedtek, egyelőre nem tapasztalható a lakosság túlzott eladósodása. Egyrészt a budapesti ingatlanárak a fundamentumok által indokolt szintjük közelében vannak․ Másrészt az adósságfék-szabályok regionális effektivitását tekintve sem azonosítható a budapesti és vidéki lakosok eladósodási folyamatai között jelentős eltérés. Budapesten a magas ingatlanár-növekedés ellenére is mintegy négy százalékponttal alacsonyabb a 70 százalék feletti HFM-értékkel rendelkező hitelek aránya, és csak 1,5 százalékponttal magasabb a két korlát által együttesen érintett szerződések volumene a Budapesten kívüli folyósításokhoz képest, ami - figyelembe véve a fővárosi magasabb jövedelmi szinteket - alátámasztja, hogy túlzott eladósodás egyelőre nem figyelhető meg. Érdemes megjegyezni, hogy amint az a 3. táblázat alapján is megállapítható, az adósságfék-szabályok a tapasztalatok szerint elsősorban a túlzott lakossági eladósodást

${ }^{7}$ Lásd bővebben az MNB Lakáspiaci jelentéseit: https://www.mnb.hu/kiadvanyok/jelentesek/lakaspiacijelentes 
képesek hatásosan mérsékelni, az ingatlanpiaci folyamatokra csak korlátozottabb hatást gyakorolhatnak, így főként a hitelezés által fütött ingatlanpiaci áremelkedésre lehetnek mérséklő hatással.

A fent leírtaknak megfelelően a jelzáloghitel-ügyletek JTM és HFM szerinti eloszlása alapján a HFM-érték tekintetében látható nagyobb mértékű csoportosulás a szabályozói limitek körül (7. ábra). Az adósságfék-előírások közül azonban az általuk visszafogott hitelek tekintetében a becsült hatás nagyobb részét eredményezte a JTM-előírás. A hatásbecslés kapcsán felhasznált eloszlásillesztések alapján ugyanis a HFM-értékek tekintetében a szabályozói limitek kevesebb hitelfelvevő esetében igényeltek alkalmazkodást a JTM-értékekhez képest (MNB 2017b).

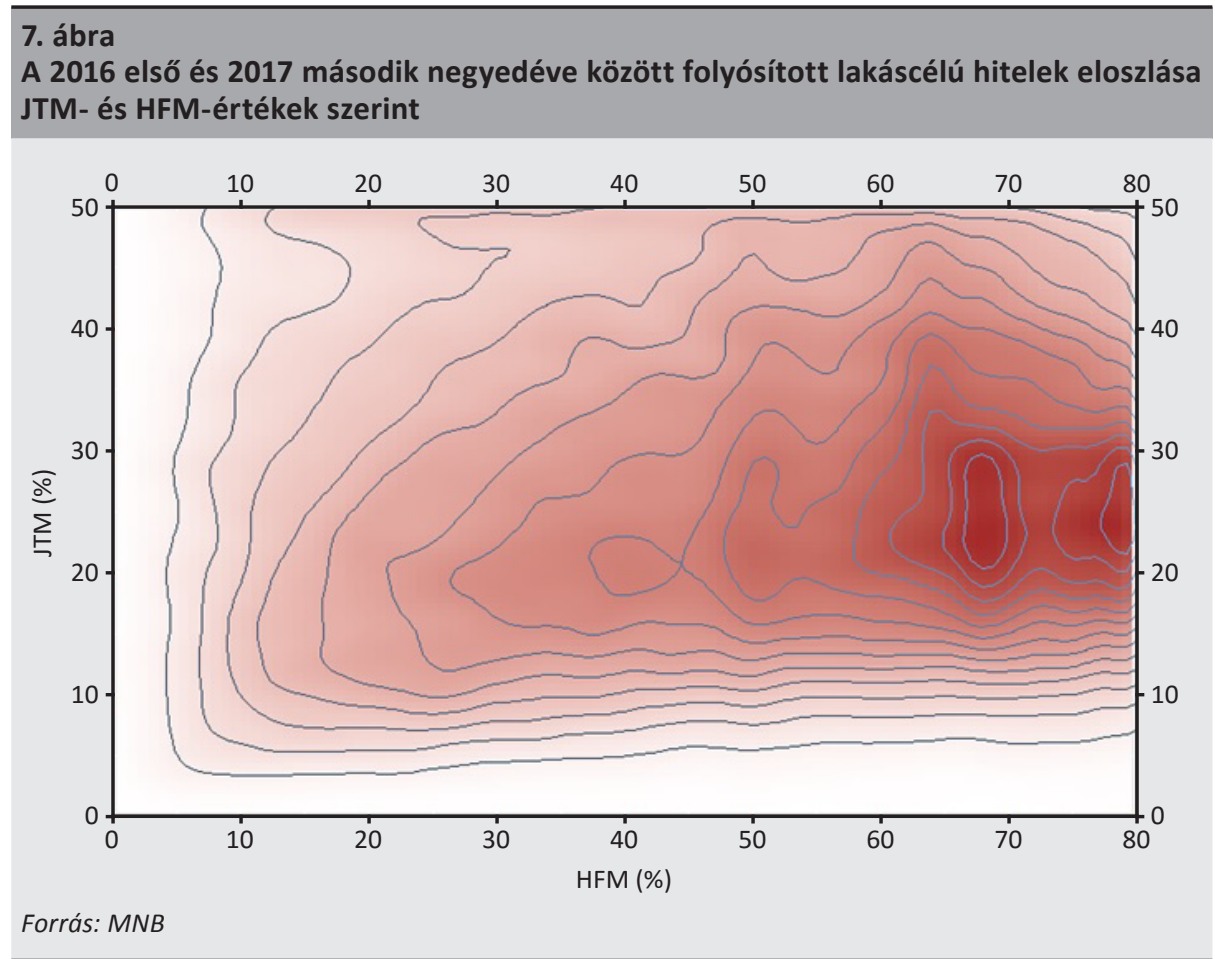

\subsection{Az adósságfék-előírások esetleges mellékhatásai}

Bár az adósságfékek ügyletszinten való hatása jelentősen mérsékli a szabályozói arbitrázs lehetőségét, az adósok és a hitelezők a szabályok pontos kialakításától függően bizonyos mértékig a hitelkiáramlást nem érintő csatornákon keresztül is alkalmazkodhatnak az előírásokhoz, ami azok fokozódó effektivitását is előre jelezheti. Ezen alkalmazkodási lehetőségeket foglalja össze a 6. táblázat. 
Amint látható, a lehetséges mellékhatások inkább a jövedelem arányában korlátozó szabályozások esetében jelentkezhetnek, amit magyarázhat egyrészt, hogy a HFM-érték kevésbé komplex módszerrel számítható. A másik ok, hogy a JTM-szabályok az összes felvett hitelre vonatkoznak, míg a HFM-előírás csak jelzáloghitel felvételekor jelent korlátozást. Mindkét jellegű előírás esetében releváns lehet a hitelfelvevők kevésbé szabályozott, nem banki közvetítői csatornák felé való terelése. Ezt a hazai szabályozás megfelelően kezeli, hiszen nem csak a banki hitelnyújtásra terjed ki a hatálya. Bár a magánszemélyek közötti hitelügyleteket az előírások nem korlátozzák, ezek online platformokon vagy személyes kapcsolatokon való elterjedése hazai viszonylatban nem figyelhető meg számottevő mértékben.

\begin{tabular}{|c|c|c|}
\hline \multicolumn{3}{|c|}{$\begin{array}{l}\text { 6. táblázat } \\
\text { Az adósok potenciális alkalmazkodási lehetőségei az adósságék-szabályokhoz }\end{array}$} \\
\hline & JTM & HFM \\
\hline $\begin{array}{c}\text { Nem banki közvetítőn keresztül } \\
\text { való hitelfelvétel }\end{array}$ & releváns, de a szabályozás kezeli & releváns, de a szabályozás kezeli \\
\hline Futamidő-hosszabbítás & $\begin{array}{c}\text { releváns, de jelenleg nem } \\
\text { jellemző }\end{array}$ & nem releváns \\
\hline $\begin{array}{c}\text { Rövidebb kamatperiódus } \\
\text { választása }\end{array}$ & $\begin{array}{c}\text { releváns, de a szabályozás } \\
\text { ellenösztönzi }\end{array}$ & nem releváns \\
\hline $\begin{array}{l}\text { Kedvezőbb kamatozású } \\
\text { devizanem választása }\end{array}$ & releváns, de a szabályozás kezeli & releváns, de a szabályozás kezeli \\
\hline Fedezetlen hitelfelvétel & nem releváns & releváns, de a szabályozás kezeli \\
\hline
\end{tabular}

Forrás: ESRB, MNB

Mivel az adósok által fizetett törlesztőrészletek nagyságát a felvett hitelösszeg, a kamat és a futamidő hármasa határozza meg, a JTM-előíráshoz való alkalmazkodás változatlan hitelösszeg esetén a kamatozás és a futamidő módosításával lehetséges:

- Kedvezőbb kamatozású konstrukciók: Ennek két jellemző módja a rövidebb kamatperiódusú hitelek vagy kedvezőbb kamatszinttel rendelkező devizanem választása lehet. Jelenleg hazánkban a devizahitelek folyósítása a mind a lakosságban, mind a hitelnyújtókban élénken élő devizahitelezési tapasztalatoknak is köszönhetően nem jellemző, az adósságfék-szabályok pedig a magasabb kockázatokat szigorúbb limitek útján korlátozzák. Bár a változó kamatozású hitelek esetében valamelyest nagyobb a jobban eladósodott hitelfelvevők aránya a hosszabb távra rögzített kamatozású hitelekhez képest, a különbség nem jelentős, a kamatperiódus szerinti alkalmazkodás pedig összességében a kamatszintek közötti különbségnek megfelelő mértékben korlátozott. A rövidebb kamatperiódusok előnyét korlátozza, hogy a JTM számításakor 2016 májusa óta a legalább 5 éves kamatperiódusú hitelek törlesztőrészlete kedvezményes, 85 százalékos súllyal kerül beszámításra, így az ugyanazon hitelösszegre jutó magasabb törlesztőrészlet nem ütközik a JTM-limitbe. 
- Hosszabb futamidő: A hosszabb futamidő törlesztőrészletre való hatása a futamidő nyújtásával egyre kisebb mértékben jelentkezik, miközben jelentősen növeli a teljes visszafizetendő összeget. Az adósságfék-szabályok bevezetése óta csak a lakáshitelek esetében látható kismértékű emelkedés, ami azonban inkább az általánosan jellemző lakásár-emelkedésnek és az emiatt észlelhető hitelösszeg-növekedésnek tudható be.

A HFM-elő́rásra jellemző mellékhatás lehet a fokozott fedezetlen hitelfelvétel. Amennyiben a hitelfelvevők nem rendelkeznek kellő mennyiségű megtakarítással, fedezetlen hitel felvételével alkalmazkodhatnak a HFM-szabályok által megkövetelt önrész-követelményhez. A hazai hitelpiacon a magasan megterhelt fedezetek esetén a lakáscélú kölcsön előtt előfordul ilyen hitelfelvétel, azonban az adósok jelenleg nem számottevő mértékben alkalmazkodnak efféle módon a HFM-szabályozáshoz. Ezen hatást ráadásul a JTM-előírás is limitálja, mivel az adósok jövedelmének adósságtörlesztésre fordítható maximális része korlátozott. A JTM ilyen esetekben való effektivitását erősíti, hogy a fedezetlen hitelek kamatai jóval magasabbak, ami az effajta alkalmazkodást jelentősen költségessé teszi.

\section{6. Összegzés}

Az adósságfék-szabályok életbelépésével kialakításra került az a szabályozói keretrendszer, amely gyors és hatásos válaszlépést tesz lehetővé a túlzott lakossági hitelezésből eredő kockázatok mérséklésére. Az előírások jelenleg nem korlátozzák érdemben a hitelezést, hatásukat várhatóan akkor fejtik majd ki, amikor a hitelezés túlzottá válik. Az elmúlt időszak adatai alapján nem látható az adósok jelentős csoportosulása a jogszabályi limitek közelében, továbbá nem azonosítható a fogyasztók jelentős mértékű alkalmazkodása sem, ezért a szabályozás céljával összhangban csak a túlzottan kockázatos hiteleket tartja vissza, egészséges szerkezetet biztosítva a válság után magára találó lakossági hitelezésnek.

A jövőben természetesen további kihívások is felmerülhetnek a hitelezési folyamatok kapcsán, amelyek kezelésére az adósságfék-szabályok - kisebb „finomhangolással" - szintén alkalmasak lehetnek. Egyrészt az ingatlanár-túlfútöttség regionálisan is jelentkezhet. Az ingatlanár-növekedés egyes, gazdaságilag fejlettebb, jellemzően fővárosi, illetve nagyvárosi régiókban erőteljesebb lehet az országoshoz képest nagyobb ingatlankereslet és az ahhoz képest szűkösebb kínálat miatt. A regionális ingatlanár-túlfútöttség mérséklésére számos ország területileg differenciált adósságfék-szabályokat vezetett be, de Magyarország esetében jelenleg ilyen jellegú differenciálást nem indokolnak a hitelezési folyamatok. Másrészt a jövőben a változó kamatozású hitelek magas aránya is kihívást jelenthet. A változó kamatozású hitelek törlesztőrészlete azonnal, vagy kis késéssel leköveti a kamatkörnyezet esetleges változását, ami annak erőteljes emelkedése esetén jelentős fogyasztási 
alkalmazkodásra késztetheti az adósokat. A nemzetközi szabályozói gyakorlatban ezért több megoldás is létezik a változó kamatozású hitelek kamatkockázatának adósságfék-szabályokban való figyelembe vételére. Nagy Britanniában és Romániában ajánlást írtak elő, Norvégiában a kezdeti ajánlást 2015-től, Szlovákiában pedig 2017 márciusától kötelező szabályozás váltja fel, Észtországban cikluson átívelő kamatszintet kell feltételezni a hitelbírálat során, ${ }^{8}$ míg Izraelben az adósoknak folyósított hitel legfeljebb egyharmada lehet változó kamatozású. ${ }^{9}$ Végül felmerülhet az adósságfék-előírások hatékonyságának további erősítése is a kötelező pozitív adóslista bevezetésével és az önkéntes központi jövedelem-lekérdezhetőség megteremtésével. A JTM meghatározásához a hitelnyújtóknak egyértelműen és hitelesen meg kell tudniuk állapítani az adósok fennálló törlesztési terhét és jövedelmét. A törlesztési teher becslésére a különböző hitel-nyilvántartások alkalmasak, azonban ezek akkor a leghatékonyabbak, ha az adós minden hitelszerződését tartalmazzák, és ha a hitelnyújtók azt az adós hozzájárulása nélkül is lekérdezhetik. A JTM-érték megállapításának másik operatív nehézsége a beszámítható stabil jövedelmek minél pontosabb, igazolható meghatározása. Egyes jövedelemtípusok ugyanis túlságosan időszakosak, így azok figyelembevétele problémás, míg más jövedelemtípusok esetén pedig azok igazolhatósága lehet nehézkes. Ezen problémára lehet megoldás az adósok hozzájárulásán alapuló, a bankok által igénybe vehető központi jövedelem-lekérdezhetőség megteremtése.

\section{Felhasznált irodalom}

Akinci, O. - Olmstead-Rumsey, J. (2015): How effective are macroprudential policies? An empirical investigation. Board of Governors of the Federal Reserve System, International Finance Discussion Papers, no 1136. https://doi.org/10.17016/IFDP.2015.1136

Anundsen, A. - Jansen, E. (2013): Self-reinforcing effects between housing prices and credit. Journal of Housing Economics. 22(3): 192-212. https://doi.org/10.1016/j.jhe.2013.07.001

Baek, E.-G. - Shin, D.-J. - Kim, B-H-S. (2013): Effect of household loan regulation on financial stability: empirical evidence from Korea. The Association of Korean Economic Studies, www.akes.or.kr/eng/papers(2013)/15.full.pdf.

Balás Tamás - Banai Ádám - Hosszú Zsuzsanna (2015): A nemteljesitési valószínúség és az optimális PTI-szint modellezése egy háztartási kérdőíves felmérés felhasználásával. MNB-tanulmányok 117.

\footnotetext{
${ }^{8}$ A kapcsolódó szabályozások gyűjteményéért lásd az ESRB adatbázisát: https://www.esrb.europa.eu/national_ policy/shared/pdf/overview_macroprudential_measures.xlsx?5eee1aeb10edcf3ab515977928325dd4

${ }_{9}^{9}$ A részletekért lásd az izraeli jegybank oldalát: http://www.boi.org.il/en/NewsAndPublications/PressReleases/ Pages/21-08-2013-loans.aspx
} 
Bauer Péter - Endrész Mariann - Kiss Regina - Kovalszky Zsolt - Martonosi Ádám Rácz Olivér - Schindler István (2013): Túlzott lakossági eladósodás: okok, trendek, következmények. MNB-Szemle, 2013. október (különszám), pp 29-38.

Béres Alexandra Dorottya - Grosz Gabriella (2016): Kötelező pozitiv adóslista: ettól lehetnek olcsóbbak a hitelek. https://www.mnb.hu/letoltes/joberes-grosz-kotelezo-pozitiv-adoslistaettol-lehetnek-olcsobbak-a-hitelek.pdf. Letöltés ideje: 2017. augusztus 2.

Berlingheri, L. (2010): Essays on House Price Fluctuations in the U.S. PhD-disszertáció, University of Washington, Seattle, USA.

Boar, C. - Gambacorta, L. - Lombardo, G. - Pereira da Silva, L. (2017): What are the effects of macroprudential policies on macroeconomic performance? BIS Quarterly Review, September: 71-88.

Boldizsár Anna - Kékesi Zsuzsa - Koroknai Péter - Sisak Balázs (2016): A magyarországi EUtranszferek áttekintése - két költségvetési időszak határán. Hitelintézeti Szemle, 15(2): 59-87.

Borio, C. - Lombardi, M. - Zampolli, F. (2016): Fiscal sustainability and the financial cycle. BIS Working Papers, no. 552.

Brissimis, S. - Vlassopoulos, T. (2009): The interaction between mortgage financing and housing prices in Greece. Journal of Real Estate Finance and Economics, 39(2): 146-164. https://doi.org/10.1007/s11146-008-9109-3

Carreras, O. - Davis, E. - Piggott, R. (2016): Macroprudential tools, transmission and modelling. National Institute of Economic and Social Research Discussion Paper, no 470. https://doi.org/10.2139/ssrn.2967270

Cerutti, E. - Claessens, S. - Laeven, L. (2017): The use and effectiveness of macroprudential policies: new evidence. Journal of Financial Stability, 28(C): 203-224. https://doi. org/10.1016/j.jfs.2015.10.004

Claessens, S. - Kose, M. - Terrones, M. (2009): What happens during recessions, crunches and busts? Economic Policy, 24(60): 653-700. https://doi.org/10.1111/j.14680327.2009.00231.x

Craig, R. - Hua, C. (2011): Determinants of property prices in Hong Kong SAR: implications for policy. IMF Working Paper, no 11/277. https://doi.org/10.5089/9781463925949.001

Crowe, C. - Dell'Ariccia, G. - Igan, D. - Rabanal, P. (2013): How to deal with real estate booms: lessons from country experiences. Journal of Financial Stability, 9(3): 300-319. https://doi.org/10.1016/j.jfs.2013.05.003 
Drehmann, M. - Juselius, M. (2014): Evaluating early warning indicators of banking crises: Satisfying policy requirements. International Journal of Forecasting, 30(3): 759-780. https://doi.org/10.1016/j.ijforecast.2013.10.002

Drehmann, M. - Juselius, M. - Korinek, A. (2017): Accounting for debt service: the painful legacy of credit booms. BIS Working Papers, no 645.

ESRB (2014): European Systemic Risk Board: The ESRB Handbook on Operationalising Macro-prudential Policy in the Banking Sector. https://www.esrb.europa.eu/pub/pdf/ other/140303_esrb_handbook_mp.en.pdf. Letöltés ideje: 2017. augusztus 10.

ESRB (2017): European Systemic Risk Board: National measures of macroprudential interest in the EU/EEA. https://www.esrb.europa.eu/national_policy/shared/pdf/overview_ macroprudential_measures.xlsx?5eee1aeb10edcf3ab515977928325dd4

Fáykiss Péter - Nagy Márton - Szombati Anikó (2017): Regionally-differentiated debt cap rules: a Hungarian perspective. In: Macroprudential frameworks, implementation and relationship with other policies. BIS Papers vol. 94, pp 153-178. Bank for International Settlements.

Fitzpatrick, T. - McQuinn, K. (2007): House prices and mortgage credit: Empirical evidence for Ireland. The Manchester School, 75(1): 82-103. https://doi.org/10.1111/j.14679957.2007.01004.x

Gerlach, S. - Peng, W. (2005): Bank lending and property prices in Hong Kong. Journal of Banking and Finance, 29(2): 431-481. https://doi.org/10.1016/j.jbankfin.2004.05.015

Geršl, A. - Jašová, M. (2014): Measures to tame credit growth: are they effective? Economic Systems, 38(1): 7-25. https://doi.org/10.1016/j.ecosys.2013.10.001

Gimeno, R. - Martinez-Carrascal, C. (2010): The relationship between house prices and house purchase loans: the Spanish case. Journal of Banking and Finance, 34(8): 1849-1855. https://doi.org/10.1016/j.jbankfin.2009.12.011

Gorton, G. - Ordoñez, G. (2016): Good Booms, Bad Booms. NBER Working Paper, no 22008. https://doi.org/10.3386/w22008

Hoffmann, B. (2003): Bank lending and property prices: some international evidence, The Hong Kong Institute for Money Research Working Paper, no 22/2003.

Hoffmann, B. (2004): The determinants of private sector credit in industrialised countries: do property prices matter? International finance, 7(2): 203-234. https://doi.org/10.1111/ j.1367-0271.2004.00136.x 
Hosszú Zsuzsanna (2011): A lakossági fogyasztás viselkedése és annak jövedelem szerinti heterogenitása a válság elött mikrostatisztikák alapján. MNB-Szemle, 2011. október: 28-35.

Igan, D. - Kang, H. (2011): Do loan-to-value and debt-to-income limits work? Evidence from Korea. IMF Working Paper, no 11/297. https://doi.org/10.5089/9781463927837.001

Jácome, L. - Mitra, S. (2015): LTV and DTI Limits-going granular. IMF Working Paper, no 15/154. https://doi.org/10.5089/9781513551449.001

Jordà, Ò. - Schularick, M. - Taylor, A-M. (2015): Leveraged bubbles. Journal of Monetary Economics, 76: S1-S20. https://doi.org/10.1016/j.jmoneco.2015.08.005

Kim, C. (2013): Macroprudential policies: Korea's experiences. Előadás a „Rethinking Macro Policy II: First Steps and Early Lessons" c. konferencián, International Monetary Fund, Washington, DC, április 16-17.

Kronick, J. (2015): Do loan-to-value ratio regulation changes affect Canadian mortgage credit? Munich Personal RePEc Archive Paper, no 73671.

Kuncl, M. (2016): Assessment of the effects of macroprudential tightening in Canada. Bank of Canada Staff Analytical Note, no 2016-12.

Kuttner, K. - Shim, I. (2013): Can non-interest rate policies stabilise housing markets? Evidence from a panel of 57 economies. NBER Working Paper, no 19723.

Lee, J-K. (2013): The operation of macro prudential policy measures the case of Korea in the 2000s. In: Canuto, O. - Ghosh, S. (szerk.): Dealing with the challenges of macro financial linkages in emerging markets, The World Bank, chapter 7.

Lim, C. - Columba, F. - Costa, A. - Kongsamut, P. - Otani, A.- Saiyid, M. - Wezel, T. - Wu, X. (2011): Macroprudential policy: what instruments and how to use them? Lessons from country experiences. IMF Working Paper, no 11/238.

McDonald, C. (2015): When is macroprudential policy effective? BIS Working Papers, no 496.

Mishkin, F-S. (2008): How should we respond to asset price bubbles? Banque de France Financial Stability Review, no 12: 65-74.

MNB (2016): Makroprudenciális jelentés - 2016. október. http://www.mnb.hu/letoltes/ makroprudencialis-jelentes-hu.pdf. Letöltés ideje: 2017. augusztus 5.

MNB (2017a): Lakáspiaci jelentés - 2017. május. https://www.mnb.hu/letoltes/lakaspiacijelentes-2017-majus-hu.pdf. Letöltés ideje: 2017. augusztus 8.

MNB (2017b): Makroprudenciális jelentés - 2017. december. https://www.mnb.hu/letoltes/ makroprudencialis-jelentes-2017.pdf. Letöltés ideje: 2017. december 14. 
Morgan, P. - Regis, P. - Salike, N. (2015): LTV policy as a macroprudential tool: the case of residential mortgage loans in Asia. Asian Development Bank Institute, Working Paper, no 528.

Neagu, F. - Tatarici, L. - Mihai, I. (2015): Implementing loan-to-value and debt serviceto-income measures: a decade of Romanian experience. National Bank of Romania, Occasional Papers, no 15.

Nouy, D. (2017): Gaming the rules or ruling the game? - How to deal with regulatory arbitrage. Előadás a 33. SUERF Kollokviumon, Helsinki, 2017. szeptember 15.

Oikarinen, E. (2009a): Household borrowing and metropolitan housing price dynamics: empirical evidence from Helsinki. Journal of Housing Economics, 18(2): 126-139. https://doi.org/10.1016/j.jhe.2009.04.001

Oikarinen, E. (2009b): Interaction between housing prices and household borrowing: the Finnish case. Journal of Banking and Finance, 33(4): 747-756. https://doi.org/10.1016/ j.jbankfin.2008.11.004

Price, G. (2014): How has the LVR restriction affected the housing market: a counterfactual analysis. Reserve Bank of New Zealand Analytical Note, no AN2014/03.

Schularick, M. - Taylor A-M. (2012): Credit Booms Gone Bust: Monetary Policy, Leverage Cycles, and Financial Crises, 1870-2008. American Economic Review, 102(2): 1029-1061. https://doi.org/10.1257/aer.102.2.1029

Szombati Anikó (2017): A makroprudenciális eszközök alkalmazásának elméleti alapjai. In: Lehmann Kristóf - Palotai Dániel - Virág Barnabás (szerk.): A magyar út - célzott jegybanki politika. Magyar Nemzeti Bank, Budapest pp 689-736.

Vandenbussche, J. - Vogel, U. - Detragiache, E. (2015): Macroprudential policies and housing prices: a new database and empirical evidence for central, eastern, and southeastern Europe, Journal of Money, Credit and Banking, 47(S1): 343-377. https://doi.org/10.1111/ jmcb.12206

Wong, E. - Tsang, A. - Kong, S. (2014): How does loan-to-value policy strengthen banks' resilience to property price shocks: evidence from Hong Kong, Hong Kong Institute for Monetary Research Working Paper, no 03/2014. 